Proceedings of the Prehistoric Society 84, 2018, pp. 185-205 (C) The Prehistoric Society. This is an Open Access article, distributed under the terms of the Creative Commons Attribution licence (http://creativecommons.org/ licenses/by/4.0/), which permits unrestricted reuse, distribution, and reproduction in any medium, provided the original work is properly cited.

doi:10.1017/ppr.2018.6 First published online 06 August 2018

\title{
Isotopic Evidence for Landscape use and the Role of Causewayed Enclosures During the Earlier Neolithic in Southern Britain
}

\author{
By SAMANTHA NEIL ${ }^{1}$, JANE EVANS ${ }^{2}$, JANET MONTGOMERY ${ }^{3}$ and CHRIS SCARRE ${ }^{3}$
}

The nature of landscape use and residence patterns during the British earlier Neolithic has often been debated. Here we use strontium and oxygen isotope analysis of tooth enamel, from individuals buried at the Hambledon Hill causewayed enclosure monument complex in Dorset, England to evaluate patterns of landscape use during the earlier Neolithic. Previous analysis suggests that a significant proportion of the artefacts found at the site may originate from lithology of Eocene and Upper to Middle Jurassic age that the enclosures overlook to the immediate west and south. The excavators therefore argued that the sector of landscape visible from Hambledon Hill provides an approximate index for the catchment occupied by the communities that it served. Most of the burial population exhibit isotope ratios that could be consistent with this argument. Connections between Hambledon Hill and regions much further afield are also bypothesised, based on the presence of artefacts within the assemblage that could have been sourced from lithology in Somerset, Devon, and Cornwall in south-west England. However, few of the sampled individuals have strontium isotope ratios consistent with having obtained the majority of their diet from such areas during childhood. The individuals who exhibit the highest strontium isotope ratios are all adult males, whom the excavators suggest to have died during one or more episodes of conflict, following the burning and destruction of surrounding defensive outworks built during the 36th century BC. At least one of these individuals, who was found with an arrowhead amongst his ribs, did not obtain his childhood diet locally and has ${ }^{87} \mathrm{Sr} /{ }^{86} \mathrm{Sr}$ values that could be comparable to those bioavailable in the south-west peninsula.

Keywords: Neolithic, Britain, causewayed enclosures, strontium, isotope analysis, diet, mobility

ARCHAEOLOGICAL EVIDENCE FOR LANDSCAPE USE \& THE ROLE OF CAUSEWAYED ENCLOSURES DURING THE EARLIER NEOLITHIC

Causewayed enclosures began to be constructed in southern Britain from the late 38th century BC (Whittle et al. 2011, 878-5; Bayliss et al. 2011, 684). The role of these earthworks, which are characterised by single or multiple concentric circuits of interrupted ditches,

\footnotetext{
${ }^{1}$ School of Archaeology, University of Oxford, 36 Beaumont St, Oxford, OX1 2PG. Email: samantha.alison.neil@gmail.com

${ }^{2}$ NERC Isotope Geosciences Laboratory, Keyworth, Nottingham, NG12 5GG, UK

${ }^{3}$ Durham University, Department of Archaeology, South Road, Durham, DH1 3LE, UK
}

has been heavily debated (eg, Evans 1988; Edmonds 1993, 102-34; Thomas 1999, 38-45; Whittle et al. 2011, 5-12; Albrecht 2011, 8-50). The presence of substantial amounts of pottery, flint knapping debris, and animal bones within the ditches initially prompted excavators to suggest they were settlements (eg, Leeds 1928, 466; Curwen 1931, 108-9; Crawford 1933, 344; 1937, 210; Wheeler 1943, 81; Case 1982, 2; Avery et al. 1982, 25; Robertson-Mackay et al. 1987, 59-60). However, in recent decades with the exception of earlier Neolithic enclosures found in the far south-west of England that may have been used for permanent settlement (Mercer 1981; 2001, 43-44; although see Davies 2010, 162-4, 176-7), interpretations 
suggest that causewayed enclosures were monuments which hosted temporary gatherings, playing a role in bringing together communities who usually resided elsewhere (eg. Smith 1965, 19; Thomas 1999, 42; Oswald et al. 2001, 123-6, 132; Cummings 2008, 142; Beadsmoore et al. 2010, 129; Whittle et al. 2011, 893-5; Thomas 2016, 7, 12). The presence of natural silting at several of these sites, interspersed with features that may demonstrate the ditches were intermittently recut, could indicate that visits to causewayed enclosures were episodic and may have been seasonal (eg, Smith 1965, 7, 20; Mercer 1988, 94; Mercer \& Healy 2008, 755; Pryor 1998, 364; Legge 2008, 554). Archaeological evidence also suggests that many of the artefacts found within the enclosure ditches were selectively deposited and that the butchered remains of cattle, also frequently found within enclosure ditches, could also be associated with feasting activity (eg, Smith 1971, 100; Whittle et al. 1999, 357; Evans \& Hodder 2006, 319; Mercer \& Healy 2008, 755, 762; Darvill et al. 2011, 139, 195; Thomas 2016; although see Parmenter et al. 2015). The presence of both articulated formal burials and disarticulated human remains within the enclosure ditches demonstrates that these sites were also associated with mortuary rites and the commemoration of the dead (eg, Drewett et al. 1977, 225-6; Pryor 1998, 362; Mercer \& Healy 2008, 759-60).

Archaeological evidence for settlement patterns during this period has also been the subject of competing interpretations. Discovery of substantial timber buildings of early 4th millennium $\mathrm{BC}$ date has been used by some authors to argue that early agriculturalists were fully sedentary and heavily reliant on intensive mixed farming, with individuals obtaining all their resources through keeping livestock and cultivating cereals close to permanently occupied settlements (eg, Rowley-Conwy 2003; 2004, 96; 2011; Rowley-Conwy \& Legge 2015). Others, however, suggest there may have been greater temporal and regional diversity in subsistence and settlement strategies during the course of the Neolithic (eg, Thomas 2013, 418). In Britain, substantial timber buildings are part of a diverse range of evidence for occupation, that also includes pits, lithic scatters, and more ephemeral structural remains (eg, Anderson-Whymark \& Thomas 2012; Brophy 2015). The latter are frequently interpreted as temporary camps and could suggest that some members of early farming communities were residentially mobile, moving episodically between occupation sites and visiting a variety of different geographical locations to obtain dietary resources (eg, Pollard 1999, 82; Whittle 1997, 21; 2003, 43; Garrow et al. 2005, 155). Some authors argue that patterns of land use and mobility may also have been structured around visitation of causewayed enclosures and suggest that these monuments 'acted as staging posts in an annual cycle of movement around loosely defined territories' (Oswald et al. 2001, 119). Rather than Neolithic communities obtaining all of their resources through year round sedentary intensive mixed farming at permanently occupied settlements, these authors propose that patterns of land use, subsistence, and mobility were complex and socio-culturally variable (eg, Thomas 2013, 411; Leary \& Kador 2016).

Analysis of material culture and the derivation of raw materials that were used to manufacture many of the artefacts found at causewayed enclosures, such as pottery and worked stone, has also been employed as a proxy for reconstructing patterns of land use. Causewayed enclosures are frequently located on the slopes of elevated promontories (Oswald et al. 2001, 91, 109-10), and are sometimes found in pairs, situated side by side on adjacent spurs of the same hilltop (ibid., 112-13; Allen et al. 2008; Healy 2008, 3; Darvill et al. 2011, 196; Dixon et al. 2011, 465). Some researchers suggest that the contrasting form and fabric of artefacts found in adjacent enclosures may indicate that each had a different functional role (Allen et al. 2008, 308-12). However, at the Hambledon Hill complex in Dorset, England, which includes two early Neolithic long barrows and two causewayed enclosures, a larger main enclosure and the smaller Stepleton enclosure situated side by side on adjacent spurs of the hill (Fig. 1), analysis of raw materials used to manufacture the majority of artefacts found within the adjacent enclosures indicates that these may have been sourced from the sector of landscape each enclosure overlooks (Smith et al. 2008, 646). Based on this discovery, the excavators propose that each enclosure could have served a distinctive social group who occupied a specific sector of the landscape (Roe 2009, 28 ) and that the immediate sector of landscape visible from each enclosure provides an approximate index of the catchment occupied by the community it served (Healy 2004, 31; Mercer \& Healy 2008, 767).

The Hambledon Hill complex was the subject of a major campaign of rescue excavation between 1974 and 1986 (Mercer \& Healy 2008, 11; Mercer 1988; 1980). Bayesian modelling of radiocarbon dates 


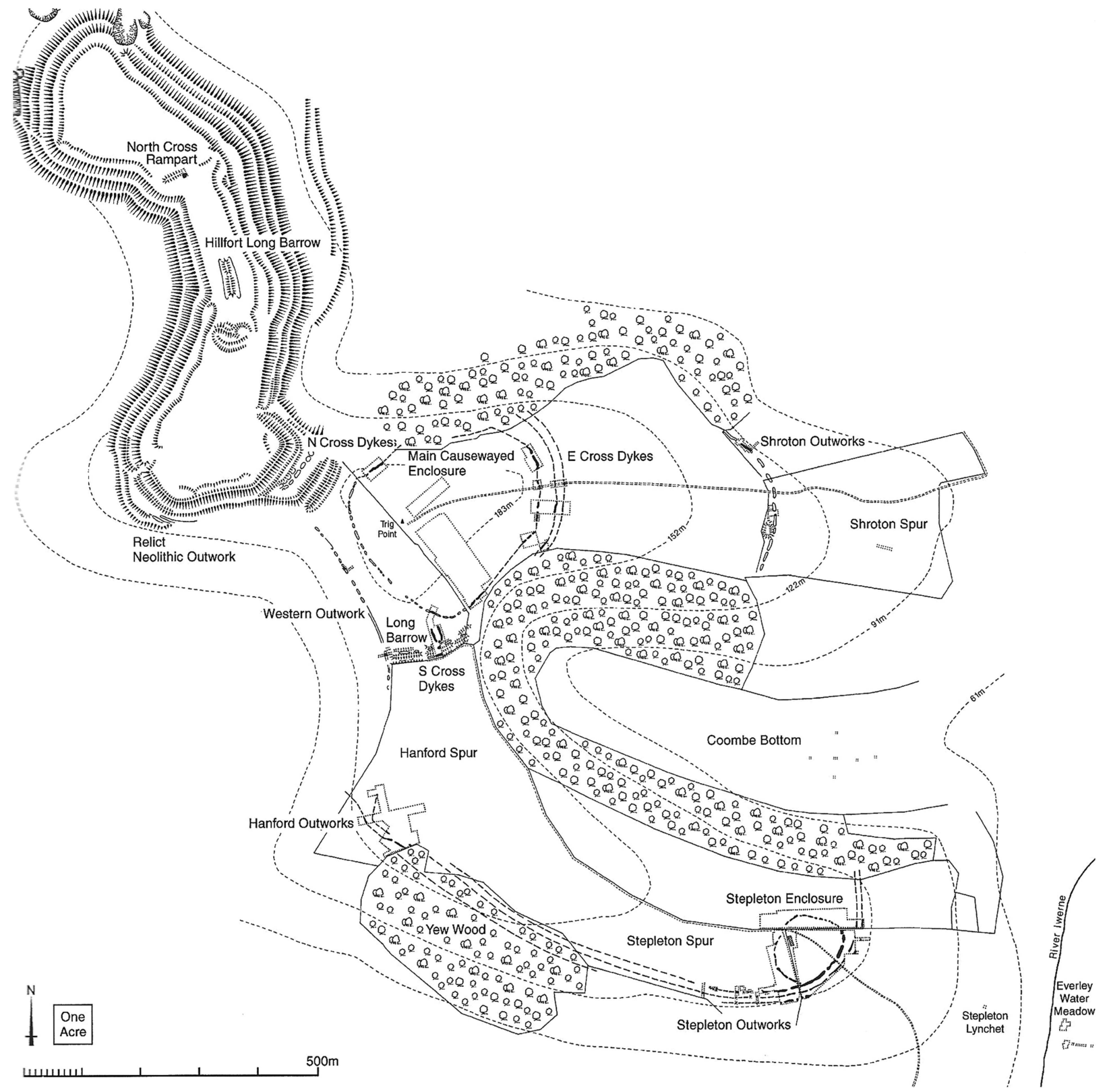

Fig. 1.

Plan of Hambledon Hill (after Mercer \& Healy 2008; reproduced with permission)

suggests early Neolithic activity on the hill began 3685-3640 cal BC and ended 3345-3305 cal BC $(95 \%$ probability, OxCal v.3.10; Healy et al. 2011, 145; also see Bayliss et al. 2008). The architecture of the very earliest dated phases of the complex includes the south long barrow and the excavators suggested that the morphology of this monument bears affinities to the architecture of long barrows found on the Cretaceous
Chalk downs to the east (Fig. 2; Mercer \& Healy 2008, 766; Mercer 2006, 70; 2009). However, despite being located in very close proximity to the Chalk, to the immediate east and north-east (Fig. 2), few of the objects found at Hambledon Hill were manufactured from Chalk or Sarsen, sources of which lie in this direction (Roe 2008, 633; Mercer \& Healy 2008, 767; Roe 2009, 27). Likewise, Decorated Bowl 

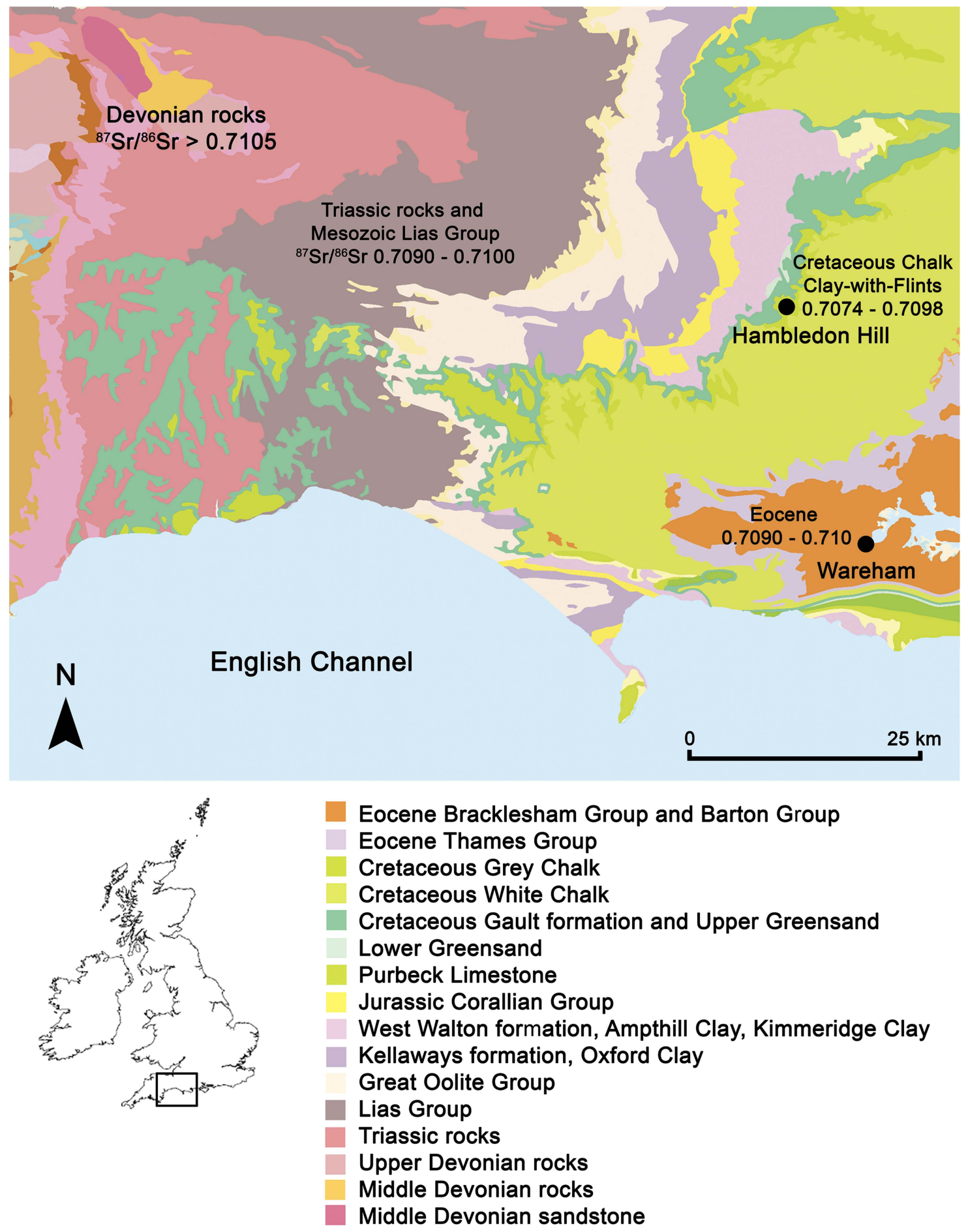

Eocene Bracklesham Group and Barton Group Eocene Thames Group Cretaceous Grey Chalk Cretaceous White Chalk Cretaceous Gault formation and Upper Greensand Lower Greensand Purbeck Limestone Jurassic Corallian Group West Walton formation, Ampthill Clay, Kimmeridge Clay Kellaways formation, Oxford Clay Great Oolite Group Lias Group Triassic rocks Upper Devonian rocks Middle Devonian rocks Middle Devonian sandstone

Fig. 2.

Location of Hambledon Hill in relation to bedrock geology and measured ${ }^{87} \mathrm{Sr} /{ }^{86} \mathrm{Sr}$ bioavailable values (Based on British Geological Survey and Ordnance Survey map data, reproduced with permission of the British Geological Survey and Ordnance Survey, () NERC/Crown copyright (2016). Bioavailable ${ }^{87} \mathrm{Sr} /{ }^{86} \mathrm{Sr}$ ranges after Montgomery et al. (2006); Evans et al. (2010); Chenery et al. (2010), \& Warham (2011)) 
pottery, which is frequently found at early Neolithic sites in the east and south-east of England (for instance, in the Thames valley, Sussex, East Anglia, and Wessex: Zienkiewicz 1999, 286; Bayliss et al. 2011, 762-3) was only a minor part of the ceramic assemblage at Hambledon (Smith 2008a, 592; also see Pioffet 2015).

Instead, analysis of material culture suggests that, for the majority of the period Hambledon Hill was in use, it was closely connected to the area of landscape that lies to the south and west. Ceramics found at the site reflect styles common to the south-western region of England (Healy 2004, 31; 2006, 11; Mercer \& Healy 2008, 591, 767). The larger main enclosure overlooks the landscape to the west (Fig. 1). Analysis of clays used to manufacture the pottery found in this enclosure suggests the majority could have been sourced from the Upper-Middle Jurassic lithologies that lie in this direction (Fig. 2): pottery fabric groups 7, 8, and 2 may have been manufactured from Kimmeridge Clay and Oolitic Limestone, which crop out to the west of the hill (Healy 2006, 11; Smith 2008a, 587, 595-6; Darvill 2008, 615, 617, 620-1). Many of the worked stone objects found within the main enclosure may also originate from sources that lie in this direction, with querns frequently being manufactured from Greensand, the closest source of which is located to the immediate west of the hill (Fig. 2; Roe 2008, 632-3).

In contrast to the main enclosure, the Stepleton enclosure (Fig. 1), situated on the adjacent spur of the hill, faces toward the coastal zone of southern Dorset. Analysis of objects suggests that both the clays used to make ceramics (fabric group 6) and worked stone found within this enclosure may derive from lithology of Eocene age located in this direction, close to the coast, approximately $25 \mathrm{~km}$ away (near to Wareham, Dorset, Fig. 2; Roe 2008, 633; 2009, 28-9; also see Smith 2008a, 587, 595; Darvill 2008, 619; Smith et al. 2008, 646; Mercer \& Healy 2008, 767). High densities of recorded finds along the coastal zone of southern Dorset indicate this region may have been a particular focus for activity during the Early Neolithic (Field 2008, 46-8). Analysis of lithics found at Hambledon Hill, which were manufactured from chert, suggests these could also have been sourced from a similar area (Saville 2008, 651).

Links between Hambledon and areas within the west and south-west of England are also implied by the presence of other materials that were imported from much further afield in this direction. Many of the quernstones found at the site were manufactured from Old Red Sandstone (Roe 2008, 632-3; Smith et al. 2008, 645-6). Devonian Old Red Sandstone crops out in several areas of Britain (Barclay et al. 2005, 3-4), the closest sources to Hambledon Hill being in Somerset and north Devon, c. $40 \mathrm{~km}$ away to the west. Connections even further afield, are also implied by the presence of Gabbroic pottery, which was imported to Hambledon from the Lizard Peninsula in Cornwall (Smith 2008a, 587, 590; Darvill 2008, 615). The majority of stone axes and adzes found at the complex also originate from sources in Cornwall (Smith 2008b, 630). Use of the causewayed enclosure complex at Hambledon was long-lived, lasting over 300 years, with both the adjacent enclosures on the hill remaining in use for much of this time (Healy et al. 2011, 145). Consistency in the sourcing of artefacts throughout this period suggests that links between Hambledon and regions to the west and south were maintained over time (Smith et al. 2008, 646; Mercer \& Healy 2008, 756-7).

Whilst being significant locations in the landscape that may have played a role in social gatherings and bringing together communities, some enclosures also appear to have been the focus of episodic conflict (Oswald et al. 2001, 128-30; Bayliss et al. 2011, 718; Whittle et al. 2011, 520). This interpretation arises from the frequent discovery of arrowheads and evidence for burning at enclosures, particularly those located within south-western England (such as Maiden Castle, Dorset: Sharples 1991, 51; Crickley Hill, Gloucestershire: Dixon 1988, 82; 2011, 460: Hembury, Devon: Mercer 1999, 151; and Carn Brae, Cornwall: Mercer 1981, 68; 2003, 61). The excavators of Hambledon Hill suggest that the deaths of four individuals, all adult males, may have occurred during episodes of conflict at the site. The deaths of two of these individuals appear to have been associated with the burning of outworks that were built to surround the site (Mercer \& Healy 2008, 760-1). The excavators suggest individual ST79 2726, who was found on the base of the inner Stepleton outwork ditch: 'may have been the victim of the catastrophe in which the defences were fired' during the mid-36th century (Healy et al. 2011, 140-1; cf. Mercer \& Healy 2008, 408), whilst the death of individual ST81 3181, who is dated to a similar period and was found in a pit containing scorched rubble and burnt clay, may also have been associated with this event (Mercer \& Healy 2008, $275,408)$. The deaths of both of these individuals appear to have been shortly followed by that of a third adult male (ST80 1875), who died 3630-3360 cal BC 
(95\% confidence) and was found lying within the Stepleton outworks, with an arrowhead amongst his ribs (Healy et al. 2011, 129, 142-3). A fourth individual, who was also found within the Stepleton outworks with an arrowhead amongst his ribs, may have died later in the history of the complex, at 3500-3130 cal вс (95\% confidence, individual ST78 2755, Healy et al. 2011, 128, 143; McKinley 2008, 512).

\section{THE APPLICATION OF ISOTOPE ANALYSIS: PRINCIPLES \& LIMITATIONS}

The excavation of the Hambledon Hill complex led to the discovery of one of the most substantial osteological assemblages of earlier Neolithic date so far found in Britain (McKinley 2008, 504). Use of isotope analysis offers a new means to examine patterns of landscape use during this period (eg, Bentley 2006; Montgomery 2010; Slovak \& Paytan 2011; Price 2015, 75-8). This study applies isotope analysis of tooth enamel to evaluate where the individuals who were buried at Hambledon Hill obtained their childhood diet.

\section{Strontium isotope analysis}

Strontium has four naturally occurring isotopes, atoms of the same chemical element that differ in atomic mass as they possess a different number of neutrons: ${ }^{84} \mathrm{Sr},{ }^{86} \mathrm{Sr},{ }^{87} \mathrm{Sr}$, and ${ }^{88} \mathrm{Sr}$ (Faure 1986, 118). Strontium-87 is radiogenic, a product of the radioactive decay of rubidium-87 $\left({ }^{87} \mathrm{Rb}\right.$; Faure \& Mensing 2005, 76; Dickin 2005, 42-3). Unlike the other isotopes of strontium, the amount of ${ }^{87} \mathrm{Sr}$ gradually increases over geological time scales and ${ }^{87} \mathrm{Sr} /{ }^{86} \mathrm{Sr}$ therefore varies geographically according to the age and initial isotope composition of bedrock. Use of strontium isotope analysis for geographic provenancing is based on the principle that humans and animals derive their dietary strontium from biosphere sources. Strontium weathers from rocks, entering soils and ground waters where it becomes available to plants (Capo et al. 1998, 202-3) and is transferred up the food chain and becomes incorporated into the mammalian skeleton (Montgomery 2002, 17, 24, 36; 2010, 328; Bentley 2006, 141; Slovak \& Paytan 2011, 7434). Conventionally measured ${ }^{87} \mathrm{Sr} /{ }^{86} \mathrm{Sr}$ values do not vary significantly between trophic levels (Graustein 1989, 492; Blum et al. 2000) and, as tooth enamel is highly resistant to diagenesis, the isotope ratios in teeth are considered to reflect sources to which an individual was exposed whilst the tooth was mineralising (Budd et al. 2000; 2001; Montgomery 2002; Madgwick et al. 2012, 741). Measured values in modern plants and waters vary with the age and composition of the underlying lithology (Montgomery et al. 2006; Evans et al 2010; Warham 2011; Frei \& Frei 2011; Willmes et al. 2013). Comparison of ${ }^{87} \mathrm{Sr} /{ }^{86} \mathrm{Sr}$ values in teeth that form at successive stages of childhood to mapped bioavailable values can as such be used to evaluate whether an individual derived dietary resources from the area in which they were buried or whether they may have obtained their childhood diet from further afield (Bentley 2006; Montgomery 2010; Slovak \& Paytan 2011, 743-4). The strontium isotope ratios that human individuals exhibit can also be compared to ${ }^{87} \mathrm{Sr} /{ }^{86} \mathrm{Sr}$ ranges bioavailable on lithologies from which artefacts (such as clays for pottery or worked stone, see above) may have been sourced.

Strontium isotope ratios within enamel are therefore a direct proxy for the geographical location from which an individual obtained their childhood diet. However, use of this methodology is also subject to limitations: when interpreting results consideration must be given to the fact that different geographical areas may have the same bioavailable range and can confer similar ${ }^{87} \mathrm{Sr} /{ }^{86} \mathrm{Sr}$ values. An individual with an ${ }^{87} \mathrm{Sr} /{ }^{86} \mathrm{Sr}$ value comparable to the local range at the site where they are buried may not, therefore, have obtained their diet locally and could have inhabited another region with the same biosphere value. This is similarly problematic when applying the technique to study consecutively mineralising molars: if an individual exhibits the same ${ }^{87} \mathrm{Sr} /{ }^{86} \mathrm{Sr}$ value in teeth that mineralise at successive stages of childhood they could either have obtained their dietary resources from the same area throughout a prolonged period during early life; alternatively they could have exploited two different geographically separate areas with similar bioavailable ranges.

For this reason there are limitations to use of this technique at Hambledon Hill, since the two immediate geographical areas to which each enclosure may have been linked through artefact analysis have overlapping ${ }^{87} \mathrm{Sr} /{ }^{86} \mathrm{Sr}$ bioavailable ranges. Upper Jurassic Kimmeridge Clay formation may have been the source for the clays used to make pottery deposited within the main enclosure (Fig. 2; see above) and samples of plants and water taken on this formation in southern Britain record measured biosphere ${ }^{87} \mathrm{Sr} /{ }^{86} \mathrm{Sr}$ values between 0.7086 and $0.7091 \quad(\mathrm{n}=10$, mean $0.7088 \pm 0.0003,2 \sigma ;$ Warham 2011, 79). The latter 
lies close to the Weymouth Member of the Oxford Clay Formation, which can record biosphere values of 0.7092-0.7097 $(\mathrm{n}=6$, mean $0.7094 \pm 0.0003,2 \sigma$; Warham 2011, 79). The region of southern Dorset to which the excavators suggest that the Stepleton enclosure was linked (Roe 2008, 633; Smith et al. 2008, 646) has been associated with a bioavailable range of 0.7090 0.7100 (Fig. 2; Evans et al. 2010). As such, if individuals exhibit ${ }^{87} \mathrm{Sr} /{ }^{86} \mathrm{Sr}$ values between $c .0 .7090$ and 0.7100 they could have sourced their diet from either of the two immediate regions to which the enclosures have been linked through analysis of material culture.

The ${ }^{87} \mathrm{Sr} /{ }^{86} \mathrm{Sr}$ ranges that are bioavailable on these lithologies may also overlap with the predicted bioavailable range at Hambledon Hill itself and that associated with the Cretaceous Chalk to the immediate east of the site. Like the lithologies that lie to the immediate east, Hambledon Hill is composed of Chalk (British Geological Survey (BGS)/Natural Environment Research Council (NERC) 2016). In Britain, samples of plants and water taken on Chalk record ${ }^{87} \mathrm{Sr} /{ }^{86} \mathrm{Sr}$ values between 0.7074 and 0.7087 (mean $0.7080 \pm 0.0008,2 \sigma, \mathrm{n}=14$; Evans 2010; Warham 2011, 124), in areas of high rainfall this may extend close to 0.7092 (Montgomery et al. 2007, 1503; Montgomery 2010, 333; although see Warham 2011, 161-2). However, superficial deposits that are characteristic of Clay-with-flints have also been found on Hambledon Hill, although due to modern ploughing activity the past extent of these deposits at this site is uncertain (Mercer \& Healy 2008, 1-5). They are also recorded on the Chalk directly east of the hill (BGS/ NERC 2016). These deposits have been shown to further extend the bioavailable range on the Chalk (Warham 2011, 123-4): in southern Britain the maximum biosphere ${ }^{87} \mathrm{Sr} /{ }^{86} \mathrm{Sr}$ value currently recorded on Clay-with-flints in an area of Chalk is 0.7098 (Warham 2011, 120; Fig. 2).

In contrast to Chalk and Clay-with-flints to the east, or to Kimmeridge Clay to the immediate west, lithology that lies further afield to the west and south-west of Hambledon is associated with higher bioavailable values (Fig. 2). The Peterborough Member of the Oxford Clay crops out just over $8 \mathrm{~km}$ to the west (BGS/NERC 2016) and, in southern Britain, samples of plants growing on this lithology record bioavailable ${ }^{87} \mathrm{Sr} /{ }^{86} \mathrm{Sr}$ values of 0.7103-0.7105 (mean $0.7104 \pm 0.0001,2 \sigma, \mathrm{n}=4$; Warham 2011, 79, 82-3). Whilst biosphere ${ }^{87} \mathrm{Sr} /{ }^{86} \mathrm{Sr}$ values higher than 0.7105 are routinely associated with lithology of Devonian and Carboniferous age, such as that found in Somerset and north Devon to the west and south-west of Hambledon Hill (Fig. 2), and with lithology of similar age beyond this in Cornwall (Evans et al. 2010; Montgomery et al. 2006).

\section{Oxygen and carbon isotope analysis}

The isotope ratios of light elements, such as oxygen $\left({ }^{18} \mathrm{O} /{ }^{16} \mathrm{O}\right)$ and carbon $\left({ }^{13} \mathrm{C} /{ }^{12} \mathrm{C}\right)$, have a relatively low atomic mass and can be readily altered as a result of mass dependent fractionation, during biological, chemical, and physical processes (Hoefs 2009, 35-6). The ratio of ${ }^{18} \mathrm{O} /{ }^{16} \mathrm{O}$ (expressed as $\delta^{18} \mathrm{O}$, see methodology below) varies geographically, due to discrimination between the heavier and lighter isotopes of oxygen that is induced by evaporation and condensation during the hydrological cycle (Sharp 2007, 74-80). The oxygen isotope composition of ground water, which ultimately derives from meteoric water, is influenced by factors such as temperature, latitude, altitude, and distance from the coast (Mook 2005; Gat 2010, 58-63). Britain receives most of its rainfall from a westerly direction and modern groundwaters in western Britain therefore record higher $\delta^{18} \mathrm{O}$ values than those in eastern Britain (Darling et al. 2003, 18990). A statistically significant difference between the mean $\delta^{18} \mathrm{O}$ values measured in tooth enamel of multiperiod archaeological populations buried in western Britain $(18.2 \pm 1 \%$ o $2 \sigma)$ from those buried in eastern Britain $(17.2 \pm 1.3 \%$, $2 \sigma)$ may reflect the underlying geographic variation in the oxygen isotope composition of local drinking water between these two areas (Evans et al. 2012, 759). These ranges were determined using the phosphate $\left(\mathrm{PO}_{4}^{3-}\right)$ fraction of tooth enamel $\left(\delta^{18} \mathrm{O}_{\text {phosphate }}\right)$. The structural carbonate $\left(\mathrm{CO}_{3}^{2-}\right)$ fraction of enamel was utilised by the present study. In tooth enamel of Holocene age, the structural carbonate fraction is considered to be resistant to diagenesis and to be equally suitable for analysis (Zazzo 2014). Chenery et al. (2012) suggest that, as values of both fractions are well correlated, conversion between the two may be undertaken to facilitate comparison between published $\delta^{18} \mathrm{O}_{\text {phosphate }}$ and $\delta^{18} \mathrm{O}_{\text {carbonate }}$ datasets (see below).

When interpreting the results of oxygen isotope analysis, consideration needs to be given to the role of culturally mediated behaviour: both culinary practices and consumption of ingested fluids that have been subject to fractionation through biological processes 
(eg, cow's milk: Kornexl et al. 1997, 22; Lin et al. 2003, 2193; Camin et al. 2008, 1695; or breast milk: Roberts et al. 1988; Wright \& Schwarcz 1998; Britton et al. 2015) may play a role in altering $\delta^{18} \mathrm{O}$ values, conferring higher values relative to local drinking water (Daux et al. 2008: 1145; Brettell et al. 2012).

Isotope analysis of the structural carbonate fraction of enamel simultaneously yields carbon isotope ratios $\left(\delta^{13} \mathrm{C}_{\text {carbonate }}\right)$ which provide additional dietary information. The use of carbon isotope analysis for this purpose exploits the large variation in natural abundance of the isotopes of carbon $\left({ }^{13} \mathrm{C} /{ }^{12} \mathrm{C}\right)$ between plants that use the two dominant $\left(\mathrm{C}_{3}\right.$ or $\left.\mathrm{C}_{4}\right)$ photosynthetic pathways during fixation of $\mathrm{CO}_{2}$ energy and the large variation in $\delta^{13} \mathrm{C}$ values between terrestrial $\mathrm{C}_{3}$ and marine ecosystems (Lee-Thorp 2008; Schwarcz \& Schoeninger 2011; Sponheimer \& Cerling 2014). Current understanding of dietary composition in the British Neolithic is based on analysis of carbon and nitrogen $\left(\delta^{13} \mathrm{C}\right.$ and $\left.\delta^{15} \mathrm{~N}\right)$ values in bone collagen, which predominantly reflect the protein component of the diet and indicate that this was overwhelmingly derived from $\mathrm{C}_{3}$ terrestrial sources (Richards \& Hedges 1999, 893; Richards et al. 2003; Hamilton and Hedges 2011; Schulting 2013; 2015). Analysis of carbon and nitrogen isotope values from bone collagen at Hambledon Hill has also previously demonstrated that the population at this site obtained dietary protein from terrestrial sources (Richards 2000, 128; $2008,524)$. In contrast to bone collagen, $\delta^{13} \mathrm{C}_{\text {carbonate }}$ values in bioapatite reflect the isotope composition of the diet as a whole (Ambrose \& Norr 1993, 2; Jim et al. 2004). Individuals who obtain all of their diet, including carbohydrates and lipids, from $\mathrm{C}_{3}$ terrestrial sources may be predicted to have $\delta^{13} \mathrm{C}_{\text {carbonate }}$ values between approximately -17.0 and $-14.0 \%$ (Kellner $\&$ Schoeninger 2007; Froehle et al. 2012).

\section{MATERIALS AND METHODS}

\section{Sample selection}

Despite the size of the excavated osteological assemblage from Hambledon Hill taphonomic factors influence sample selection and hence the representativeness of isotope results. As discussed above, strontium isotope analysis is undertaken on tooth enamel, therefore ante-mortem tooth loss or severe attrition to enamel can preclude sampling. Mortuary practice is also influential in determining whether dentition is present and therefore whether an individual will be represented within the sampled group. The human burial assemblage from Hambledon Hill is estimated to contain a minimum number of 75-77 individuals (McKinley 2008, 490). Not all of these individuals, however, have dentition. The assemblage comprises skeletons in varied states of articulation (ibid., 51214) and the presence of partly articulated skeletons and cutmarks on human bone suggest that excarnation may have been practised (ibid., 516; Mercer 1980, 63; Mercer \& Healy 2008, 759). Fragmentary and disarticulated skeletal remains also exhibit signs of weathering and whilst they could represent the terminal phase of a mortuary rite that was practised within the confines of the complex itself, it is also possible that elements were curated and brought to the complex from burial contexts elsewhere (McKinley 2008, 514; Mercer \& Healy 2008, 760; cf. Whittle et al. 1999, 362). Construction of the complex and its duration of use are very well dated, with dates having been obtained from short-lived material that was deposited in the ditches and from articulated skeletal remains (Bayliss et al. 2008; Healy et al. 2011, 11157). However, it remains a possibility that disarticulated skeletal elements, which are identified in Table S1(Appendix S1), are older than the contexts in which they were deposited. Were this the case, the isotope results from teeth in disarticulated mandibles could represent a population older than, or ancestral to, the community who deposited them.

As the burial assemblage contains fragmentary disarticulated remains, care had to be taken to avoid the potential for duplication of isotope results through sampling of cross-matching elements belonging to the same individual. To avoid this, a consistent strategy of sampling the left mandibular dentition was adopted. Maxillary teeth were not sampled. Loose teeth or teeth from right mandibular fragments were not used, unless it could be stated with confidence that they derived from an individual who had not previously been sampled. This strategy was only varied if it was possible to determine that the same individual would not be sampled twice (for instance, teeth from the right-hand side of a complete mandible could be used if those on the left had been lost ante-/post-mortem). As noted above, once formed, enamel is considered to be highly resistant to diagenesis; however, following Montgomery (2002, 128 ) all the teeth selected were completely mineralised and none of those sampled exhibited any visual evidence of poor preservation (carious lesions, discolouration, or staining to the enamel). 
Dentition that met these criteria was sampled, wherever present, from all excavated Neolithic contexts, including both causewayed enclosures (the main enclosure and that on Stepleton spur), the south long barrow, and the Hanford Outworks and the inner east cross dyke that surround the causewayed enclosures (Appendix S1; Fig. S1; Table S1). A total of 22 individuals, just under a third of the minimum number of individuals estimated to be present within the burial population, possessed dentition that was suitable for sampling following these criteria. Wherever present, samples were also taken from consecutively mineralising molars, to facilitate comparison of isotope ratios at different stages of childhood and adolescence. Development of the crown of the first permanent adult molar commences in utero, just prior to birth and completes by $c .4 .5 \pm 0.5$ years of age, whilst the second molar crown forms between $2.5 \pm 0.5$ and $8.5 \pm 0.5$ years (AlQahtani et al. 2010; Hillson 2014, $31,55-6)$. The timing of third molar formation is most variable (Liversidge 2008, 313), with initial cusp formation taking place at $c .8 .5 \pm 0.5$ years and crown completion by $c .14 .5 \pm 0.5$ years (AlQahtani et al. 2010).

\section{Sample preparation and laboratory analysis}

A total of 43 samples were processed following procedures developed by Montgomery (2002, 131-8). Surface enamel was thoroughly abraded using a tungsten carbide dental burr. Enamel chips were then cut using a flexible diamondedged rotary saw and surfaces, again mechanically cleaned using a dental burr to remove any adhering dentine. The resulting chips of core enamel were transferred to clean sealed containers. Dental saws and burrs were cleaned ultrasonically for 5 minutes and rinsed three times in high purity de-ionised water between preparation of samples.

Core enamel chips were transferred to the Class 100, HEPA-filtered laboratory facilities at the Natural Environment Research Council Isotope Geosciences Laboratory (NIGL, Keyworth, Nottingham, England). Enamel chips were cleaned ultrasonically and rinsed in high purity water (Millipore Alpha Q). They were then dried, weighed into pre-cleaned Teflon beakers and spiked with a known amount of ${ }^{84} \mathrm{Sr}$ tracer solution to obtain strontium concentrations. Each sample was dissolved in Teflon distilled $8 \mathrm{M} \mathrm{HNO}_{3}$. Samples were converted to Chloride using $6 \mathrm{M}$ $\mathrm{HCl}$, taken up in titrated $2.5 \mathrm{M} \mathrm{HCl}$ and pipetted onto ion exchange chromatography columns. Strontium was separated with Dowex ${ }^{\circledR}$ (AG50-X8) resin (200-400 mesh). Procedural blanks were below $100 \mathrm{pg}$. Samples were loaded on to Re filaments using a method adapted from Birck (1986, 79). Strontium isotope composition and concentrations were then determined by thermal ionisation mass spectrometry
(TIMS) using a ThermoTriton automated multi-collector mass spectrometer. To correct for fractionation during the process of mass spectrometry ${ }^{87} \mathrm{Sr} /{ }^{86} \mathrm{Sr}$ values are normalised to the accepted value for ${ }^{88} \mathrm{Sr} /{ }^{86} \mathrm{Sr}=0.1194$. During the period of this study the machine gave a value for the international standard for ${ }^{87} \mathrm{Sr} /{ }^{86} \mathrm{Sr}$ (NBS 987) of $0.710253 \pm 0.000012(2 \sigma$, $\mathrm{n}=350$ ).

Preparation of core enamel chips for $\delta^{18} \mathrm{O}$ and $\delta^{13} \mathrm{C}$ analysis was undertaken using the same methods employed above for strontium isotope analysis. Following preparation chips of core enamel were transferred to NIGL where they were powdered. Oxygen $\left(\delta^{18} \mathrm{O}_{\text {carbonate }}\right)$ and carbon $\left(\delta^{13} \mathrm{C}_{\text {carbonate }}\right)$ isotope ratios in the carbonate fraction of enamel were determined using the method outlined in Chenery et al. $(2012,310)$. Isotope ratios are reported as delta $(\delta)$ values, in parts per thousand (per mil; \%o) normalised to the VPDB scale using an in-house carbonate reference material, Keyworth Carrera Marble (KCM) which is calibrated against NBS19 certified reference material. Analytical reproducibility for this run of KCM was $\pm 0.09 \%$ \% $(1 \sigma, n=14)$ for $\delta^{18} O$ and for $\delta^{13} C \pm 0.04 \% o(1 \sigma, n=14)$. $\delta^{18} \mathrm{O}_{\text {carbonate }}$ values were normalized to the VSMOW scale using the equation of Coplen 1988 (VSMOW $=1.03091 \times$ $\delta^{18} \mathrm{O}$ VPDB +30.91$)$. Conversion between $\delta^{18} \mathrm{O}_{\text {carbonate }}$ to $\delta^{18} \mathrm{O}_{\text {phosphate }}$ was then undertaken using the regression equation of Chenery et al. $\left(2012,310 ; \delta^{18} \mathrm{O}_{\text {phosphate }}=\right.$ $\left.1.0322 \times \delta^{18} \mathrm{O}_{\text {carbonate }}-9.6849\right)$. The error involved in calculating $\delta^{18} \mathrm{O}_{\text {phosphate }}$ is considered to be low $(0.28 \%$, $1 \sigma$, Chenery et al. 2012, 313).

\section{Results}

Seventeen of the 22 sampled individuals have ${ }^{87} \mathrm{Sr} /{ }^{86} \mathrm{Sr}$ values between 0.7074 and 0.7098 (Fig. 3; Appendix $\mathrm{S} 1$; Table S1; Fig. S1). This ${ }^{87} \mathrm{Sr} /{ }^{86} \mathrm{Sr}$ range is common to the majority of individuals from a variety of different excavated contexts, including the main enclosure, the Stepleton spur enclosure and south long barrow and to individuals of different age and sex (where this information is available, following McKinley 2008). The majority of both those individuals who are represented by disarticulated mandibles and those whose skeletal remains were found in an articulated state exhibit values in this range (Table S1). With the exception of the adult males, whose deaths are suggested to have been associated with a specific episode during the history of the complex (see below), the majority of individuals who have been directly radiocarbon dated also possess values within this range. For example, both an adult male (ST79 2025) who is dated early in the history of the site to 3710$3530 \mathrm{cal} \mathrm{BC}$ and a child who died at 5-6 years of age (HH76 3046) and was buried toward the end of use of the complex (3500-3090 cal BC, 95\% confidence: 


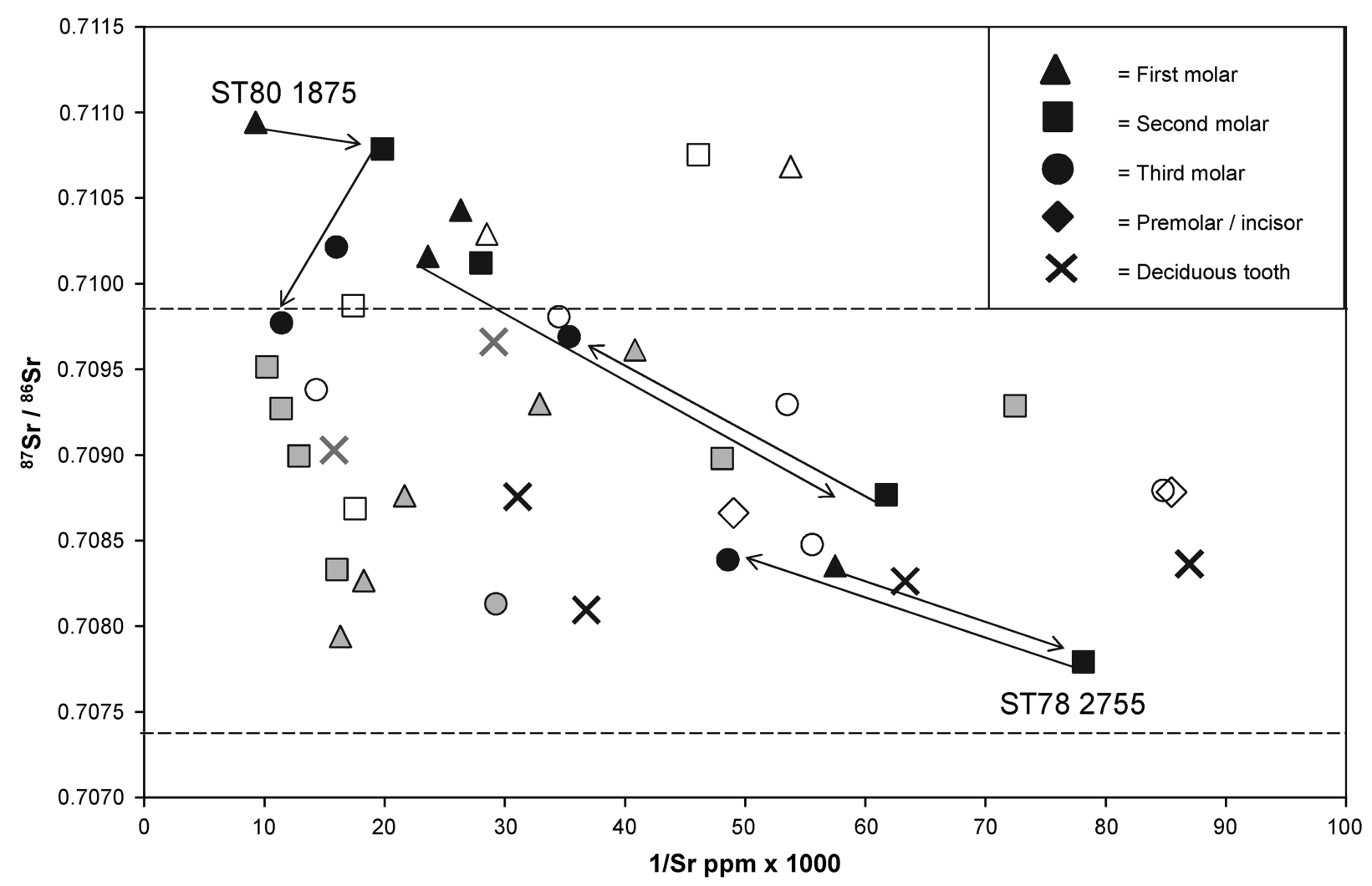

Fig. 3.

Plot of strontium isotope ratio \& elemental concentration. Dashed lines denote the predicted biosphere range at Hambledon Hill, in an area of Chalk where superficial deposits of Clay-with-flints are known to be present (based on current measured values by Warham 2011, 120,124). Black triangles, squares, \& circles: adult males buried on Stepleton spur who are inferred to have died during episodes of conflict, labelled individuals are those who were found in association with arrowheads. Arrows in the diagram illustrate adjacent sequentially forming molar teeth from these individuals. Open white symbols: individuals excavated from Stepleton spur, the south long barrow, \& the inner east cross dyke. Grey triangles, squares \& circles: individuals excavated from the main enclosure. Grey crosses: deciduous teeth of children excavated from the main causewayed enclosure. Black crosses: deciduous teeth of children excavated from Stepleton spur and the Hanford outworks. $2 \sigma$ errors for ${ }^{87} \mathrm{Sr} /{ }^{86} \mathrm{Sr}$ are within the symbol

Healy et al. 2011, 121, 127) exhibit similar ${ }^{87} \mathrm{Sr} /{ }^{86} \mathrm{Sr}$ values of 0.7087 and 0.7090 respectively. Strontium concentrations range from $12 \mathrm{ppm}$ to $108 \mathrm{ppm}$ (mean $41 \pm 26 \mathrm{ppm}, 1 \sigma, \mathrm{n}=43$ ), consistent with values previously reported for human archaeological populations buried in Britain (Evans et al. 2012, 756).

Only five individuals possess at least one tooth with an ${ }^{87} \mathrm{Sr} /{ }^{86} \mathrm{Sr}$ value higher than 0.7098 . All are adults. Two of these are represented by disarticulated fragmentary remains: individual ST78 1100/ST78 204, who may be female, was excavated from the inner Stepleton outwork (McKinley 2008, 487) and has ${ }^{87} \mathrm{Sr} /{ }^{86} \mathrm{Sr}$ values higher than 0.7105 in both their first and second permanent molars. Enamel from the permanent molar of individual HH75 1340, whose fragmentary mandibular remains were found in the inner east cross dyke, gave an ${ }^{87} \mathrm{Sr} /{ }^{86} \mathrm{Sr}$ value of 0.71029 . The other three are adult males who may have suffered a violent death in the mid-later 36th century BC (ST79 2726, ST81 3181 and ST80 1875; illustrated as black symbols in Figs 3 and 4). Individual ST80 1875, who was found with an arrowhead amongst his ribs, has the highest ${ }^{87} \mathrm{Sr} /{ }^{86} \mathrm{Sr}$ values and the highest strontium concentration $(>100 \mathrm{ppm})$ in the sampled burial population, with enamel from both their first and second permanent molar teeth giving strontium isotope ratios higher than 0.7105 (Figs $3 \&$ 4; Mercer \& Healy 2008, 325). In contrast, the fourth adult male, also found in the Stepleton outworks with an arrowhead amongst his ribs but who may have died 
S. Neil et al. ISOTOPIC EVIDENCE, LANDSCAPE USE \& CAUSEWAYED ENCLOSURES, S. BRITAIN

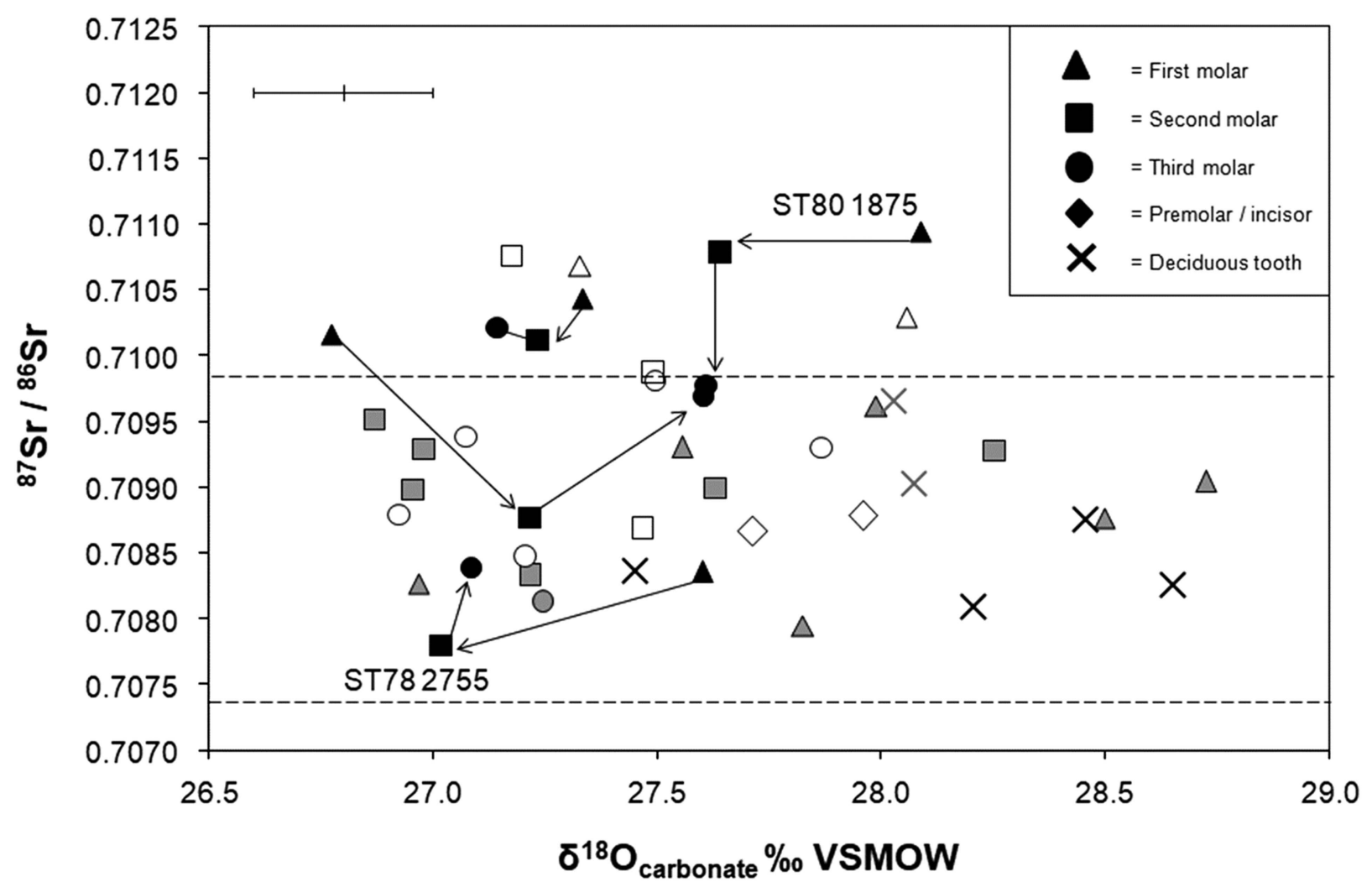

Fig. 4.

Plot of ${ }^{87} \mathrm{Sr} /{ }^{86} \mathrm{Sr}$ versus $\delta^{18} \mathrm{O}_{\text {carbonate. }}$ Dashed lines denote the predicted biosphere range at Hambledon Hill as for Fig. 3. Symbols and arrows as for Fig. $3.2 \sigma$ errors for ${ }^{87} \mathrm{Sr} /{ }^{86} \mathrm{Sr}$ are within the symbol. Analytical error for $\delta^{18} \mathrm{O}_{\text {carbonate }}$ is shown as $\pm 0.2 \% \circ(2 \sigma)$

later in the history of the complex (individual ST78 2755, labelled in Fig. 3; McKinley 2008, 512; Healy et al. 2011, 128, 143), has the lowest ${ }^{87} \mathrm{Sr} /{ }^{86} \mathrm{Sr}$ value $(0.7077)$ within the sampled population, with enamel from all three permanent molars recording values below 0.7085 .

Enamel $\delta^{18} \mathrm{O}_{\text {carbonate }}$ values range between $26.8 \%$ o and $28.7 \%$ (mean $27.6 \pm 0.5 \%$ o, $1 \sigma, \mathrm{n}=43$ ). With the exception of early forming deciduous teeth and first molars which more frequently plot with values that are higher than $28.0 \%$ (crosses in Fig. 4), the majority of enamel samples gave $\delta^{18} \mathrm{O}_{\text {carbonate }}$ values between $27.0 \%$ and $28.0 \%$. This range is common amongst sexed males and females (McKinley 2008, 478-9; Table S1) and to both articulated and non-articulated individuals from different contexts, from Stepleton spur, the main enclosure, long barrow and inner east cross dyke. The $\delta^{13} \mathrm{C}_{\text {carbonate }}$ values range between $16.8 \%$ and $-14.2 \%$ (mean $15.9 \pm 0.5 \%$ o, $1 \sigma, \mathrm{n}=43$; Table S1). There is no discernible variation in $\delta^{13} \mathrm{C}_{\text {carbonate }}$ values with tooth type, with ${ }^{87} \mathrm{Sr} /{ }^{86} \mathrm{Sr}$ or $\delta^{18} \mathrm{O}_{\text {carbonate }}$ values, or with burial context or sex. All enamel samples from Hambledon Hill fall within the range of values that may be expected for individuals who had a diet dominated by use of $\mathrm{C}_{3}$ terrestrial resources. This is consistent with previous observations based on carbon and nitrogen isotope analysis of bone collagen from this site, which showed that the population also obtained their dietary protein from terrestrial sources (Richards 2000, 128; 2008, 524).

\section{DISCUSSION}

The presence of artefacts at Hambledon Hill that were manufactured from imported materials originating from at least $40 \mathrm{~km}$ away within regions such as Somerset, Devon, and Cornwall, suggests there were long distance connections between the site and the south-west peninsula of England (Smith 2008a, 587, 
590; 2008b, 630; Darvill 2008, 615; Roe 2008, 6323; Mercer 2008, 775). However, with the exception of those individuals who may have died during an episode of violence and have more radiogenic ${ }^{87} \mathrm{Sr} /{ }^{86} \mathrm{Sr}$ values (close to 0.7105 , Fig. 2), most of the burial population do not exhibit strontium isotope ratios consistent with having sourced the majority of their childhood diet from these regions in the south-west.

Rather than routinely exploiting more distant radiogenic terrains, the majority of the sampled burial group have values that fall within locally bioavailable ${ }^{87} \mathrm{Sr} /{ }^{86} \mathrm{Sr}$ ranges (Fig. 2; Montgomery et al. 2006; Evans et al. 2010; Warham 2011). Although alternative areas further afield also afford similar bioavailable ${ }^{87} \mathrm{Sr} /{ }^{86} \mathrm{Sr}$ values (see below), a large proportion of the artefact assemblage may originate from lithologies that the causewayed enclosures directly overlook, within approximately $30 \mathrm{~km}$ of Hambledon Hill, to the immediate south and west (Smith et al. 2008, 645-6; Mercer \& Healy 2008, 767). Individuals who plot with strontium isotope ratios between 0.7086 and 0.7091 have values that are comparable to those recorded on Kimmeridge Clay formation (mean $0.7088 \pm 0.0003,2 \sigma, \mathrm{n}=10$; Warham 2011: 79). This crops out to the immediate west of the hill and was used to manufacture a large proportion of the pottery deposited within the main enclosure (Smith 2008a, 587, 595 -6; Darvill 2008, 620-1). Lithology of Eocene age in southern Dorset (near Wareham, Fig. 2), which could have been the source for much of the worked stone found at Hambledon Hill (Roe 2008, 633; Smith et al. 2008, 646), has also been associated with a similar bioavailable ${ }^{87} \mathrm{Sr} /{ }^{86} \mathrm{Sr}$ range, approximately ${ }^{87} \mathrm{Sr} /{ }^{86} \mathrm{Sr} 0.7090-0.7100$ (Fig. 2; Evans et al. 2010). Individuals who plot with ${ }^{87} \mathrm{Sr} /{ }^{86} \mathrm{Sr}$ values between $c .0 .7090$ and 0.7100 could therefore have sourced the majority of their diet from either of the immediate areas to the west and south, to which the enclosures are linked through derivation of artefacts.

Few objects made of Chalk or Sarsen were found at Hambledon Hill (Mercer \& Healy 2008, 767; Roe 2008, 633). The excavators therefore suggest that connections between the site and this lithology, to the immediate east, were limited (Fig. 2). However, several individuals within the burial population have low ${ }^{87} \mathrm{Sr} /{ }^{86} \mathrm{Sr}$ values that are comparable to those bioavailable on Chalk: in southern Britain this routinely records bioavailable values, between 0.7074 and 0.7087 (mean $0.7080 \pm 0.0008,2 \sigma, \mathrm{n}=14$; Evans 2010; Warham
2011, 124). Strontium isotope ratios in this range have previously been recorded amongst individuals buried at Monkton-up-Wimborne, on Chalk just to the east in Cranborne Chase, dated later in the 4th millennium BC (Montgomery et al. 2000, 375; Healy et al. 2011, 156). The possibility that those individuals buried at Hambledon who have ${ }^{87} \mathrm{Sr} /{ }^{86} \mathrm{Sr}$ values below c. 0.7085 obtained their diet from a similar area on the Chalk cannot be ruled out (Figs 2-4), while those who exhibit values up to $\sim 0.7098$ may also have obtained their dietary resources from the immediately local Chalk, or Clay-with-flints (see above).

Although samples of plants and water taken on Chalk record low ${ }^{87} \mathrm{Sr} /{ }^{86} \mathrm{Sr}$ values, below 0.7085 , other marine carbonates such as Oolitic Limestone, Greensand and Gault Formation, which crop out to the west of the hill (Fig. 2) could, alternatively, confer similarly low biosphere values: in southern Britain biosphere samples taken on Oolitic Limestone can record strontium isotope ratios between 0.7076 and 0.7092 (mean $0.7086 \pm 0.0004,1 \sigma, \mathrm{n}=17$; Montgomery et al. 2006, 1628; Chenery et al. 2010, 155; Warham 2011, 79, 103; for values on Greensand and Gault see Warham 2011, 79). Individuals who exhibit strontium isotope ratios below 0.7085 (Figs $3 \& 4$ ) could similarly have obtained their dietary resources on these lithologies. Analysis of the ceramics found at Hambledon suggests that Oolitic Limestone may have been used to manufacture pottery fabric group 2 (Smith 2008a, 587, 595-6; Darvill 2008, 615, 617), whilst Greensand was also used to make many of the quern stones (Roe 2008, 632).

Discussion of the range of strontium isotope ratios that the Hambledon burial population exhibit has focused on comparison of ${ }^{87} \mathrm{Sr} /{ }^{86} \mathrm{Sr}$ values to bioavailable ranges on lithologies used to manufacture the artefacts. Analysis of material culture provides persuasive evidence for links between Hambledon Hill and more immediate areas of lithology in south-west England. However, the possibility that ${ }^{87} \mathrm{Sr} /{ }^{86} \mathrm{Sr}$ values, between 0.7090 and 0.7100 , for example, could reflect use of more distant terrains, rather than those within the immediate vicinity of the site, should also be considered.

Strontium isotope ratios between 0.7090 and 0.7100 are widely bioavailable in eastern England, for example (Evans et al 2010), or north-eastern France or the Netherlands (Willmes et al. 2013; Kootker et al. 2016). The argument that the burial population at Hambledon Hill obtained childhood dietary resources 
locally from the west of England could be supported by the range of oxygen isotope ratios that this burial population exhibit. If converted to $\delta^{18} \mathrm{O}_{\text {phosphate }}$ using the equation of Chenery et al. (2012), values in second and third permanent molar enamel are in the range $18.0-19.5 \%$ (mean $18.5 \pm 0.4 \%, 1 \sigma, \mathrm{n}=23$ ), which is

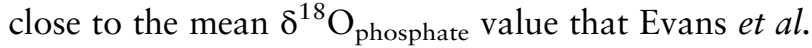
$(2012,759)$ suggest to be representative of analysed burial populations in western $(18.2 \pm 1 \%$ o $2 \sigma)$, rather than eastern Britain $(17.2 \pm 1.3 \%, 2 \sigma)$. However, this assumes that $\delta^{18} \mathrm{O}$ values in human enamel directly reflect underlying geographical variation in the oxygen isotope composition of drinking waters and that values at Hambledon Hill have not been significantly modified as a result of culinary practice (e.g. Brettell et al. 2012), or influenced by consumption of fluids that have undergone fractionation through biological processes such as cow's milk (see above). Deciduous teeth and first permanent molars, which begin to form in utero and continue to form in the months following birth (Hillson 2014, 31, 55-6), were excluded from the above comparisons. As development of these teeth may coincide with breastfeeding it is also possible that values may be influenced by consumption of breast milk, which has a higher $\delta^{18} \mathrm{O}$ value relative to meteoric water as a result of the metabolic fractiona-

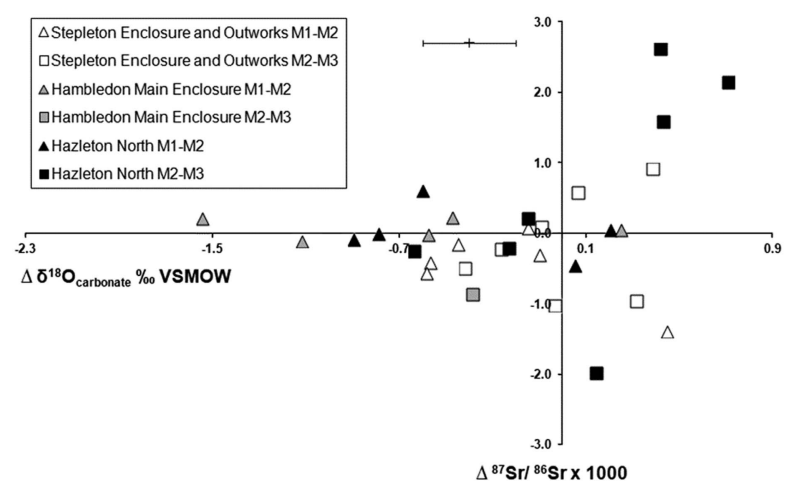

Fig. 5.

Plot of the difference in oxygen $\left(\Delta \delta^{18} \mathrm{O}_{\text {carbonate }}\right.$ VSMOW $\%$ o) and strontium $\left(\Delta^{87} \mathrm{Sr} /{ }^{86} \mathrm{Sr} \times 1000\right)$ isotope ratios between adjacent permanent molar teeth of individuals excavated from the Hambledon Hill complex \& Hazleton North long cairn, Gloucestershire (Neil et al. 2016).

Triangles: the difference in oxygen \& strontium isotope ratios between first $\&$ second permanent molar teeth.

Squares:the difference in oxygen $\&$ strontium isotope ratios between second $\&$ third permanent molar teeth. $2 \sigma$ errors for ${ }^{87} \mathrm{Sr} /{ }^{86} \mathrm{Sr}$ are within the symbol. Analytical error for $\delta^{18} \mathrm{O}_{\text {carbonate }}$ is shown as $\pm 0.2 \% \circ(2 \sigma)$ tion that occurs in the mother's body (Roberts et al. 1988, R625; Wright \& Schwarcz 1998, 13-14; Britton et al. 2015,2). Unlike the majority of second and third permanent molar teeth, many deciduous teeth and first permanent molars in this study exhibit $\delta^{18} \mathrm{O}_{\text {carbonate }}$ values that are higher than $28.0 \%$ (Fig. 4). These early forming teeth also have a higher mean $\delta^{18} \mathrm{O}_{\text {phosphate }}$ value $(19.0 \pm 0.6 \%$ o, $1 \sigma, \mathrm{n}=18)$, than that of the second and third permanent molars discussed above. There is a drop in $\delta^{18} \mathrm{O}$ carbonate values between enamel from adjacent permanent first and second molars, illustrated in Figure 5 by a negative difference between the first and second molars, which may also be a consequence of weaning.

A similar drop in $\delta^{18} \mathrm{O}$ carbonate values between adjacent permanent first and second molar enamel was also observed amongst another earlier Neolithic burial population, at Hazleton North long cairn, Gloucestershire (Fig. 5; Neil et al. 2016). This cairn was constructed in 3710-3655 cal BC $(95 \%$ probability, OxCal v. 3.5) and the burials there may, therefore, be contemporary with the earliest phase of Neolithic activity at Hambledon Hill (Saville 1990; Meadows et al. 2007, 54). At Hazleton North, large shifts in ${ }^{87} \mathrm{Sr} /{ }^{86} \mathrm{Sr}$ values and elemental concentration between adjacent permanent molar teeth (Fig. 6) are consistent

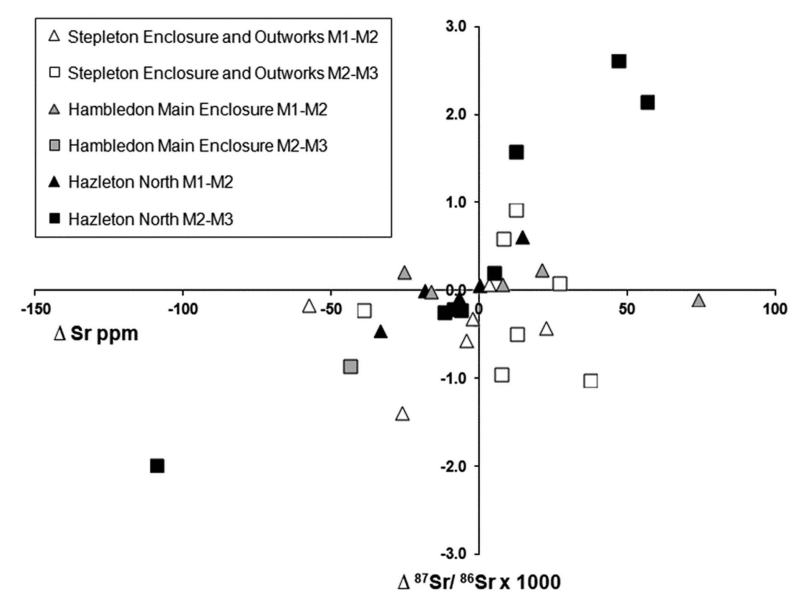

Fig. 6.

Plot of the difference in strontium isotope ratio $\left(\Delta^{87} \mathrm{Sr} /{ }^{86} \mathrm{Sr}\right.$ $\times 1000)$ and elemental concentration $(\Delta \mathrm{Sr}$ ppm) between adjacent permanent molar teeth of individuals excavated from the Hambledon Hill complex \& Hazleton North long cairn, Gloucestershire. Triangles: the difference in strontium isotope ratio \& Sr ppm between first $\&$ second permanent molars. Squares: the difference in strontium isotope ratio $\&$ Sr ppm between second \& third permanent molars. $2 \sigma$ errors for ${ }^{87} \mathrm{Sr} /{ }^{86} \mathrm{Sr}$ are within the symbol 
with individuals having routinely changed the geographical location from which they sourced their diet during childhood and support the interpretation that individuals were residentially mobile (Neil et al. 2016).

Individuals buried at Hambledon Hill do not exhibit such large shifts in strontium isotope ratio and elemental concentration between sampled adjacent molars (Fig. 6). The majority have similar strontium isotope ratios on adjacent teeth, which could be consistent either with individuals having obtained all their dietary resources from the same locality over a prolonged period during early life, or with exploitation of different, geographically separate areas that conferred a similar averaged ${ }^{87} \mathrm{Sr} /{ }^{86} \mathrm{Sr}$ value. For example, enamel samples from all three adjacent molars of individual ST78 2755 gave ${ }^{87} \mathrm{Sr} /{ }^{86} \mathrm{Sr}$ values below 0.7085 (labelled on Fig. 3). This individual, who may have met a violent end, died toward the end of the period that the Neolithic monument complex at Hambledon Hill was in use (Healy et al. 2011, 128, 143). Similarly low values on all three adjacent molars could suggest that this individual sourced his diet from the same geographical location from birth until about 15 years of age, at which time the crown of the third molar is usually complete (AlQahtani et al. 2010). Alternatively, this individual could have obtained his diet from geographically separate locations that have similar bioavailable ${ }^{87} \mathrm{Sr} /{ }^{86} \mathrm{Sr}$ ranges, for example, by moving backward and forward between an area of Oolitic Limestone and the Chalk downs in southern England.

By contrast, the other three adult males who could have died during a previous episode of conflict during the 36th century BC (see above; Mercer \& Healy 2008, 760-1), have the highest ${ }^{87} \mathrm{Sr} /{ }^{86} \mathrm{Sr}$ values in the sampled group (black symbols on Figs $3 \& 4$ ). These individuals have strontium isotope ratios that are higher than bioavailable ranges currently known to be associated with lithology in the immediate vicinity of Hambledon Hill: all possess at least one permanent molar tooth with an ${ }^{87} \mathrm{Sr} /{ }^{86} \mathrm{Sr}$ value greater than 0.7100 which therefore exceed values that are currently known to be bioavailable on immediately local Kimmeridge Clay and Chalk, or on lithology of Eocene age along the south Dorset coast (Fig. 2; Evans et al. 2010; Warham 2011). Two of these individuals (ST79 2726 \& ST81 3181) have strontium isotope ratios between 0.7101 and 0.7104 (Table S1). As described above, biosphere ${ }^{87} \mathrm{Sr} /{ }^{86} \mathrm{Sr}$ values up to 0.7105 can be recorded on the Peterborough Member of the Oxford Clay in southern Britain (mean
$0.7104 \pm 0.0001,2 \sigma, \mathrm{n}=4$; Warham 2011, 79, 82-3) which crops out just over $8 \mathrm{~km}$ to the west of Hambledon Hill (BGS/NERC 2016). As such it is possible that individuals with values up to 0.7105 need not have obtained the majority of their diet a great distance from Hambledon Hill. Alternatively, lithologies further afield within south-western England also record comparable values, for example, samples of plants and water taken on Devonian rocks within Cornwall can give measured values between 0.7100 and 0.7110 (Evans et al. 2010).

The third individual, ST80 1875, who was found with an arrowhead amongst his ribs, has the highest ${ }^{87} \mathrm{Sr} /{ }^{86} \mathrm{Sr}$ values of all of those who were sampled (Figs $3 \& 4$ ). Enamel samples from both the first and second molar teeth of this individual gave ${ }^{87} \mathrm{Sr} /{ }^{86} \mathrm{Sr}$ values greater than 0.7105 . According to all currently available ${ }^{87} \mathrm{Sr} /{ }^{86} \mathrm{Sr}$ biosphere data, values above 0.7105 are not known to be associated with lithologies of comparable age and composition to those that surround Hambledon Hill (Warham 2011, 79, 82; also see Evans et al. 2010). This individual could not, therefore, have obtained his dietary resources locally but derived his diet from more radiogenic sources further afield until at least 9 years of age, by which stage mineralisation of the crown of the second molar tooth is normally complete (AlQahtani et al. 2010). Although other areas within Britain, or the European mainland, can record bioavailable values higher than 0.7105 (eg Evans et al. 2010; Willmes et al. 2013), analysis of artefacts provides strong support for the existence of links between this site and lithology in the south-west peninsula (Smith 2008a, 590-1; 2008b, 630; Smith et al. 2008, 645; Roe 2008, 632-3). Somerset, Devon, and Cornwall in south-western England record bioavailable values higher than 0.7105 and it is possible that this individual obtained dietary resources from these areas during childhood (Montgomery et al. 2006; Evans et al. 2010).

\section{CONCLUSIONS}

Previous analysis of material culture found at Hambledon Hill indicates that a significant proportion of the raw materials used to manufacture ceramics and worked stone may have originated from lithology of Eocene and Upper-Middle Jurassic age, in the more immediate local area which the enclosures overlook to the south and west of the hill, within approximately $30 \mathrm{~km}$ (Roe 2008; Darvill 2008; Smith et al. 2008). 
The excavators therefore suggested that the immediate area of landscape visible from each enclosure provides an approximate index of the catchment which was occupied by the communities who used the site (Mercer \& Healy 2008, 767; Healy 2004, 31). Whilst other areas have been considered that could provide comparable isotope ratios, the majority of the sampled group exhibit values that could be consistent with this hypothesis. Longer distance connections, between Hambledon Hill and areas further afield within the south-west peninsula of England, are implied by the presence of objects that could originate from lithology within Somerset, Devon, and Cornwall (Roe 2008; Smith et al. 2008). However, few of the individuals in the sampled group have ${ }^{87} \mathrm{Sr} /{ }^{86} \mathrm{Sr}$ values that would be consistent with having obtained the majority of their diet from these regions during childhood and adolescence. The individuals who have the highest values in the sampled group are those who the excavators suggest died during one or more episodes of conflict, which involved burning and destruction of outworks that surround the hill, during the 36th century BC (Mercer \& Healy 2008; Healy et al. 2011). At least one of these adult males could not have sourced his childhood diet locally. This individual, who was found within the outworks that surround the site with an arrowhead amongst his ribs, obtained his diet from further afield during early life. The individual has ${ }^{87} \mathrm{Sr} /{ }^{86} \mathrm{Sr}$ values that are consistent with those bioavailable within Somerset, Devon and Cornwall within the south-west peninsula of England, the area from which previous analysis of material culture suggests that artefacts were imported.

Acknowledgements: We would particularly like to thank Hilary Sloane (NERC Isotope Geosciences Laboratory) for analytical support; Professor Roger Mercer for discussion of the excavation and provision of figure 1; Jon Murden and Richard Breward for permission to undertake sampling and the exceptional team of volunteers at Dorset County Museum for facilitating access to the museum collections. S.N. and J.E. undertook the analysis; S.N. wrote the paper. All authors discussed the manuscript. S.N. designed the research; laboratory analysis was funded through NIGFSC grant IP-1290-0512; S.N. was funded through a Durham University Doctoral Studentship award.

\section{SUPPLEMENTARY MATERIAL}

To view the supplementary material for this article, please visit https://doi.org/10.1017/ppr.2018.6

\section{BIBLIOGRAPHY}

Albrecht, B. G. 2011. A Study of Activity at Neolithic Causewayed Enclosures within the British Isles. Unpublished $\mathrm{PhD}$ thesis, Newcastle University

Allen, M.J., Leivers, M., Ellis, C., Stevens, S., Clelland, S., Bayliss, A., Butler, C., Gale, R., Gibson, A., McKinley, J., Knight, S., Mepham, L., Scaife, R. \& Stevens, C.J. 2008. Neolithic causewayed enclosures and later prehistoric farming: duality, imposition and the role of predecessors at Kingsborough, Isle of Sheppey, Kent, UK. Proceedings of the Prehistoric Society 74, 235-322

AlQahtani, S.J., Hector, M.P. \& Liversidge, H.M. 2010. Brief communication: The London atlas of human tooth development and eruption. American Journal of Physical Anthropology 142, 481-90

Ambrose, S.H. \& Norr, L. 1993. Experimental evidence for the relationship of the carbon isotope ratios of whole diet and dietary protein to those of bone collagen and carbonate. In Lambert J.B. \& Norr, L. (eds), Prehistoric Human Bone: Archaeology at the molecular level, 1-38. New York: Springer

Anderson-Whymark, H. \& Thomas, J. (eds), 2012. Regional Perspectives on Neolithic Pit Deposition: Beyond the mundane. Oxford: Neolithic Studies Group Seminar Papers 12

Avery, M., Cain, A.J., Case, H.J., Cram, C.L, Cummins, W.A., Harrison, G.A., Murphy, P., Powell, P., Startin, D.W.A., Western, A.C., Whittle, A.W.R. \& Williams, D.F. 1982. The Neolithic causewayed enclosure, Abingdon. In Case, H. J. \& Whittle, A.W. R. (eds), Settlement Patterns in the Oxford Region: Excavations at the Abingdon causewayed enclosure and other sites, 10-50. London: Council for British Archaeology Research Report 44

Barclay, W.J., Browne, M.A.E., McMillan, A.A., Pickett, E.A., Stone, P. \& Wilby, P.R. 2005. The Old Red Sandstone of Great Britain. Peterborough: Geological Conservation Review Series 31

Bayliss, A., Healy, F., Bronk Ramsey, C., McCormac, F.G. \& Mercer, R. 2008. Interpreting chronology. In Mercer, R. \& Healy, F. 2008 (eds), Hambledon Hill, Dorset, England: Excavation and survey of a Neolithic monument complex and its surrounding landscape 1, 78-411. Swindon: English Heritage

Bayliss, A., Healy, F., Whittle, A. \& Cooney, G. 2011. Neolithic narratives: British and Irish enclosures in their timescapes. In Whittle et al. (eds) 2011, 682-47

Beadsmoore, E., Garrow, D. \& Knight, M. 2010. Refitting Etton: space, time, and material culture within a causewayed enclosure in Cambridgeshire. Proceedings of the Prehistoric Society 76, 115-34

Bentley, A. 2006. Strontium isotopes from the earth to the archaeological skeleton: ArReview. Journal of Archaeological Method and Theory 13(3), 135-87

Birck, J.L. 1986. Precision K-Rb-Sr isotopic analysis application to $\mathrm{Rb}-\mathrm{Sr}$ chronology. Chemical Geology 56, $73-83$

Blum, J.D., Taliaferro, E.H., Weisse, M.T. \& Holmes, R.T. 2000. Changes in $\mathrm{Sr} / \mathrm{Ca}, \mathrm{Ba} / \mathrm{Ca}$ and ${ }^{87} \mathrm{Sr} /{ }^{86} \mathrm{Sr}$ ratios 
between two forest ecosystems in the north-eastern USA. Biogeochemistry 49, 87-101

Brettell, R., Montgomery, J. \& Evans, J. 2012. Brewing and stewing: the effect of culturally mediated behaviour on the oxygen isotope composition of ingested fluids and the implications for human provenance studies. Journal of Analytical Atomic Spectrometry 27(5), 778-85

British Geological Survey (BGS)/Natural Environment Research Council (NERC) 2016. DiGMapGB-50 (1:50 000 scale). Available online: www.bgs.ac.uk

Britton, K., Fuller, B.T., Tütken, T., Mays, S. \& Richards, M.P. 2015. Oxygen isotope analysis of human bone phosphate evidences weaning age in archaeological populations. American Journal of Physical Anthropology 157(2), 226-41

Brophy, K. 2015. Houses, halls, and occupation in Britain and Ireland. In Fowler, C., Harding, J. \& Hofmann, D. (eds), The Oxford Handbook of Neolithic Europe, 32744. Oxford: Oxford University Press

Budd, P., Montgomery, J., Barreiro, R.G. \& Thomas, R.G. 2000. Differential diagenesis of strontium in archaeological human dental tissues. Applied Geochemisty 15, 687-94

Budd, P., Montgomery, J., Evans, J. A. \& Chenery, C. 2001. Combined $\mathrm{Pb}-, \mathrm{Sr}-$ and $\mathrm{O}$-isotope analysis of human dental tissue for the reconstruction of archaeological residential mobility. In Holland, J.G. \& Tanner, S.D. (eds), Plasma Source Mass Spectrometry: The new millennium, 311-26. Cambridge: Royal Society of Chemistry Special Publication 267

Burgess, C., Topping, P., Mordant, C. \& Maddison, M. (eds), 1988. Enclosures and Defences in the Neolithic of Western Europe. Oxford: British Archaeological Report S403

Capo, R.C, Stewart, B.W \& Chadwick, O.A. 1998. Strontium isotopes as tracers of ecosystem processes: Theory and methods. Geoderma 82(1-3), 197-225

Camin, F., Perini, M., Colombari, G., Bontempo, L. \& Versini, G. 2008. Influence of dietary composition on the carbon, nitrogen, oxygen and hydrogen stable isotope ratios of milk. Rapid Communications in Mass Spectrometry 22(11), 1690-696

Case, H.J. 1982. Settlement patterns in the Oxford region: An outline. In Case, H.J. \& Whittle, A.W. R. (eds), Settlement Patterns in the Oxford Region: Excavations at the Abingdon causewayed enclosure and other sites, 1-10. London: Council for British Archaeology Research Reports 44

Chenery, C., Müldner, G., Evans, J.A., Eckardt, H. \& Lewis, M. 2010. Strontium and stable isotope evidence for diet and mobility in Roman Gloucester, UK. Journal of Archaeological Science 37(1), 150-63

Chenery, C.A., Pashley, V., Lamb, A.L., Sloane, H.J. \& Evans, J.A. 2012. The oxygen isotope relationship between the phosphate and structural carbonate fractions of human bioapatite. Rapid Communications in Mass Spectrometry 26(3), 309-19

Coplen, T.B. 1988. Normalization of oxygen and hydrogen isotope data. Chemical Geology 72, 293-97

Crawford, O.G.S. 1933. The 'interrupted ditch': a possible explanation. Antiquity 7(27), 344-45
Crawford, O.G.S. 1937. Causewayed settlements. Antiquity 11(42), 210-12

Cummings, V. 2008. The architecture of monuments. In Pollard, J. (ed.) Prehistoric Britain, 135-59. Oxford: Blackwell

Curwen, E.C. 1931. Excavations in the Trundle. Sussex Archaeological Collections 72, 100-49

Darling, W.G., Bath, A.H. \& Talbot, J.C. 2003. The O and $\mathrm{H}$ stable isotopic composition of fresh waters in the British Isles. 2. Surface waters and groundwater. Hydrology and Earth System Sciences 7, 183-95

Darvill, T. 2008. Petrological analysis of Neolithic pottery fabrics. In Mercer \& Healy (eds) 2008, 613-21

Darvill, T., Bayliss, A., Costen, D., Hambleton, E., Healy, F., Housley, R. A., O’Connell, L., Pollard, M., Snashall, N., Whittle, A., Constant, V. \& Gray, L. 2011. Excavations at a Neolithic enclosure on The Peak, near Birdlip, Gloucestershire. Proceedings of the Prehistoric Society 77, 139-204

Daux, V., Lecuyer, C., Heran, M-A., Amiot, R., Simon, L., Fourel, F., Martineau, F., Lynnerup, N., Reychler, H. \& Escarguel, G. 2008. Oxygen isotope fractionation between human phosphate and water revisited. Journal of Human Evolution 55, 1138-147

Davies, S.R. 2010. The Early Neolithic Tor Enclosures of Southwest Britain. Unpublished PhD thesis, University of Birmingham

Dickin, A.P. 2005. Radiogenic Isotope Geology, (2 edn). Cambridge: Cambridge University Press

Dixon, P. 1988. The Neolithic settlements on Crickley Hill. In Burgess et al. (eds) 1988, 75-87

Dixon, P., Bayliss, A., Healy, F., Whittle, A. \& Darvill, T. 2011. The Cotswolds. In Whittle et al. (eds), 2011, 434-75

Drewett, P., Cartwright, C.R., James, B., Thomas, K.D. \& O'Connor, T.P. 1977. The excavation of a Neolithic causewayed enclosure on Offham Hill, East Sussex, 1976. Proceedings of the Prehistoric Society 43, 201-42

Edmonds, M. 1993. Interpreting causewayed enclosures in the past and the present. In Tilley, C. (ed.), Interpretative Archaeology, 99-142. Oxford: Berg

Evans, C. 1988. Monuments and analogy: the interpretation of causewayed enclosures. In Burgess et al. (eds), 1988, 47-73

Evans, C. \& Hodder, I. 2006. A Woodland Archaeology: Neolithic sites at Haddenham 1. Cambridge: McDonald Institute for Archaeological Research

Evans, J.A., Montgomery, J., Wildman, G. \& Boulton, N. 2010. Spatial variations in biosphere ${ }^{87} \mathrm{Sr} /{ }^{86} \mathrm{Sr}$ in Britain. Journal of the Geological Society 167, 1-4

Evans, J.A., Chenery, C.A. \& Montgomery, J. 2012. A summary of strontium and oxygen isotope variation in archaeological human tooth enamel excavated from Britain. Journal of Analytical Atomic Spectrometry 27 (5), 754-64

Faure, G. 1986. Principles of Isotope Geology. New York: Wiley

Faure, G. \& Mensing, T.M. 2005. Isotopes: Principles and applications, (3 edn). Hoboken: Wiley 
Field, D. 2008. Use of Land in Central Southern England During the Neolithic and Early Bronze Age. Oxford: British Archaeological Report 458

Frei, K.M. \& Frei, R. 2011. The geographic distribution of strontium isotopes in Danish surface waters - a base for provenance studies in archaeology, hydrology and agriculture. Applied geochemistry 26, 326-40

Froehle, A.W., Kellner, C.M. \& Schoeninger, M.J. 2012. Multivariate carbon and nitrogen stable isotope model for the reconstruction of prehistoric human diet. American Journal of Physical Anthropology 147(3), 352-69

Garrow, D., Beadsmoore, E. \& Knight, M. 2005. Pit clusters and the temporality of occupation: an earlier Neolithic site at Kilverstone, Thetford, Norfolk. Proceedings of the Prehistoric Society 71, 139-57

Gat, J.R. 2010. Isotope Hydrology: A study of the water cycle. London: Imperial College Press

Graustein, W.C. $1989 .{ }^{87} \mathrm{Sr} /{ }^{86} \mathrm{Sr}$ ratios measure the sources and flow of strontium in terrestrial ecosystems. In Rundel, P.W., Ehleringer, J.R. \& Nagy, K.A. (eds), Stable Isotopes in Ecological Research, 491-512. New York: Springer

Hamilton, J. \& Hedges, R.E.M. 2011. Carbon and nitrogen stable isotope values of animals and humans from causewayed enclosures. In Whittle et al. (eds), 2011, $670-81$

Healy, F. 2004. Hambledon Hill and its implications. In Cleal, R.M.J. \& Pollard, J. (eds), Monuments and Material Culture: Papers in honour of an Avebury archaeologist Isobel Smith, 15-38. Salisbury: Hobnob Press

Healy, F. 2006. Pottery deposition at Hambledon Hill. In Gibson, A. (ed.), Prehistoric Pottery: Some recent research, 11-39. Oxford: British Archaeological Report S1509

Healy, F. 2008. Causewayed Enclosures and the Early Neolithic: The chronology and character of monument building and settlement in Kent, Surrey and Sussex in the early to mid-4th millennium cal bc. South East Research Framework Resource Assessment. London: English Heritage

Healy, F., Bayliss, A., Whittle, A., Allen, M.J., Mercer, R., Rawlings, M., Sharples, N. \& Thomas, N. 2011. South Wessex. In Whittle et al. (eds), 2011, 111-206

Hillson, S. 2014. Tooth Development in Human Evolution and Bioarchaeology. Cambridge: Cambridge University Press

Hoefs, J. 2009. Stable Isotope Geochemistry, (6 edn). Berlin: Springer

Jim, S., Ambrose, S.H. \& Evershed, R.P. 2004. Stable carbon isotopic evidence for differences in the dietary origin of bone cholesterol, collagen and apatite: implications for their use in palaeodietary reconstruction. Geochimica et Cosmochimica Acta 68(1), 61-72

Kellner, C.M. \& Schoeninger, M.J. 2007. A simple carbon isotope model for reconstructing prehistoric human diet. American Journal of Physical Anthropology 133(4), 1112-127

Kootker, L.M., Lanen, R.J., van, Kars, H. \& Davies, G.R. 2016. Strontium isoscapes in the Netherlands. Spatial variations in ${ }^{87} \mathrm{Sr} /{ }^{86} \mathrm{Sr}$ as a proxy for palaeomobility. Journal of Archaeological Science Report 6, 1-13

Kornexl, B.E., Werner, R., Rossmann, A. \& Schmidt, H.-L. 1997. Measurement of stable isotope abundances in milk and milk ingredients - A possible tool for origin assignment and quality control. Zeitschrift für LebensmittelUntersuchung und -Forschung 205(1), 19-24

Leary, J. \& Kador, T. 2016. Movement and mobility in the Neolithic. Moving on in Neolithic Studies: Understanding mobile lives, 14-27. Oxford: Neolithic Studies Group Seminar Papers 14

Leeds, E.T. 1928. A Neolithic site at Abingdon, Berkshire. Antiquaries Journal 8(4), 461-77

Lee-Thorpe, J.A. 2008. On isotopes and old bones. Archaeometry 50(6), 925-50

Legge, A.J. 2008. Livestock and Neolithic society at Hambledon Hill. In Mercer \& Healy (eds), 2008, 536-86

Lin, G.P., Rau, Y.H., Chen, Y.F., Chou, C.C. \& Fu, W.G. 2003. Measurements of $\delta \mathrm{D}$ and $\delta^{18} \mathrm{O}$ stable isotope ratios in milk. Journal of Food Science 69, 2192-5

Liversidge, H.M. 2008. Timing of human mandibular third molar formation. Annals of Human Biology 35(3), 294-321

Madgwick, R., Mulville, J. \& Evans, J. 2012. Investigating diagenesis and the suitability of porcine enamel for strontium $\left({ }^{87} \mathrm{Sr} /{ }^{86} \mathrm{Sr}\right)$ isotope analysis. Journal of Analytical Atomic Spectrometry 27(5), 733-42

McKinley, J. 2008. Human remains. In Mercer \& Healy (eds), 2008, 477-522

Meadows, J., Barclay, A. \& Bayliss, A. 2007. A short passage of time: the dating of the Hazleton long cairn revisited. Cambridge Archaeological Journal 17(1), 45-64

Mercer, R. J. 1980. Hambledon Hill, A Neolithic Landscape. Edinburgh: Edinburgh University Press

Mercer, R.J. 1981. Excavations at Carn Brea, Illogan, Cornwall 1970-73: a Neolithic fortified complex of the third millennium bc. Cornish Archaeology 20, 1-204

Mercer, R.J. 1988. Hambledon Hill, Dorset, England. In Burgess et al. (eds), 1988, 89-106

Mercer, R.J. 1999. The origins of warfare in the British Isles. In Carman, J \& Harding, A. (eds), Ancient Warfare, 14356. Stroud: Sutton

Mercer, R.J. 2001. Neolithic enclosed settlements in Cornwall and the past, present and future. In Darvill, T. \& Thomas, J (eds), Neolithic Enclosures in Atlantic Northwest Europe, 43-9. Oxford: Neolithic Studies Group Seminar Papers 6

Mercer, R.J. 2003. The early farming settlement of southwestern England in the Neolithic. In Armit, I., Murphy, E., Nelis, E. \& Simpson, D. (eds), Neolithic Settlement in Ireland and Western Britain, 56-70. Oxford: Oxbow Books

Mercer, R. 2006. The first known enclosures in southern Britain: their nature, function and role, in space and time. In Harding, A.F., Sievers, S. \& Venclová, N. (eds), Enclosing the Past: Inside and outside in prehistory, 69-75. Sheffield: J.R. Collis

Mercer, R. 2008. Hambledon among causewayed enclosures. In Mercer \& Healy (eds) 2008772-7 
Mercer, R.J. 2009. Hambledon Hill. British Archaeology $107,38-43$

Mercer, R. \& Healy, F. (eds). 2008. Hambledon Hill, Dorset, England: Excavation and survey of a Neolithic monument complex and its surrounding landscape. Swindon: English Heritage

Montgomery, J. 2002. Lead and Strontium Isotope Compositions of Human Dental Tissues as an Indicator of Ancient Exposure and Population Dynamics: The application of isotope source-tracing methods to identify migrants among British archaeological burials and a consideration of ante-mortem uptake, tissue stability and post-mortem diagenesis. Unpublished $\mathrm{PhD}$ thesis, University of Bradford

Montgomery, J. 2010. Passports from the past: investigating human dispersals using strontium isotope analysis of tooth enamel. Annals of Human Biology 37(3), 325-46

Montgomery, J., Budd, P. \& Evans, J.A. 2000. Reconstructing the lifetime movements of ancient people: a Neolithic case study from southern England. European Journal of Archaeology 3, 370-85

Montgomery, J., Evans, J.A. \& Cooper, R.E. 2007. Resolving archaeological populations with $\mathrm{Sr}$ - isotope mixing models. Applied Geochemistry 22, 1502-514

Montgomery, J., Evans, J.A. \& Wildman, G. $2006 .{ }^{87} \mathrm{Sr} /{ }^{86} \mathrm{Sr}$ isotope composition of bottled British mineral waters for environmental and forensic purposes. Applied Geochemistry 21, 1626-634

Mook, W.G. 2005. Introduction to Isotope Hydrology: Stable and radioactive isotopes of hydrogen, carbon, and oxygen. London: IAH International Contributions to Hydrogeology 25

Neil, S., Evans, J., Montgomery, J. \& Scarre, C. 2016. Isotopic evidence for residential mobility of farming communities during the transition to agriculture in Britain. Royal Society Open Science 3 http://dx.doi.org/ 10.1098/rsos.150522

Oswald, A., Dyer, C. \& Barber, M. 2001. The Creation of Monuments: Neolithic causewayed enclosures in the British Isles. London: English Heritage

Parmenter, P.C., Johnson, E.V. \& Outram, A.K. 2015. Inventing the Neolithic? Putting evidence-based interpretation back into the study of faunal remains from causewayed enclosures. World Archaeology 47(5), 819-33

Pioffet, H. 2015. Sociétés et Identités du Premier Néolithique de Grande-Bretagne et d'Irlande dans leur contexte ouest européen: caractérisation et analyses comparatives des productions céramiques entre Manche, Mer d'Irlande et Mer $d u$ Nord. Unpublished PhD thesis, Durham University \& Université de Rennes 1

Pollard, J. 1999. These places have their moments: thoughts on settlement practices in the British Neolithic. In Brück, J \& Goodman, M. (eds), Making Places in the Prehistoric World: Themes in settlement archaeology, 76-93. London: University College London Press

Price, T.D. 2015. An introduction to the isotopic studies of ancient human remains. Journal of the North Atlantic 7, $71-87$
Pryor, F. 1998. Synthesis and discussion. In Pryor, F. (ed.), Etton: Excavations at a Neolithic causewayed enclosure near Maxey, Cambridgeshire, 1982-7, 351-80. London: English Heritage

Richards, M.P. 2000. Human consumption of plant foods in the British Neolithic: direct evidence from bone stable isotopes. In Fairbairn, A.S. (ed.), Plants in the Neolithic Britain and Beyond, 123-35. Oxford: Neolithic Studies Group Seminar Papers 5

Richards, M.P. 2008. Stable isotope values. In Mercer \& Healy (eds) 2008, 522-7

Richards, M.P. \& Hedges, R.E.M. 1999. A Neolithic revolution? New evidence of diet in the British Neolithic. Antiquity 73, 891-97

Richards, M.P., Schulting, R.J. \& Hedges, R.E. 2003. Archaeology: sharp shift in diet at onset of Neolithic. Nature 425(6956), 366

Roberts, S.B., Coward, W.A., Ewing, G.J.S., Cole, T.J. \& Lucas, A. 1988. Effect of weaning on accuracy of doubly labelled water method in infants. American Journal of Physiology - Regulatory, Integrative and Comparative Physiology 254, R622-7

Robertson-Mackay, R., Butcher, S., Cameron, F., Chandra, H., Conway, B., Dawes, J., Dimes, F., Grigson, C., Healey, E., Helbaek, H. \& Higgs, E. 1987. The Neolithic causewayed enclosure at Staines, Surrey: excavations 1961-63. Proceedings of the Prehistoric Society 53, 23-128

Roe, F. 2008. Worked stone other than axes and adzes. In Mercer \& Healy (eds) 2008, 632-40

Roe, F. 2009. Corn grinding in southern England: What can querns tell us?. In Brophy, K. \& Barclay, G. (eds), Defining a Regional Neolithic: The evidence from Britain and Ireland, 26-34. Oxford: Neolithic Studies Group Seminar Papers 9

Rowley-Conwy, P. 2003. No fixed abode? Nomadism in the Northwest European Neolithic. In Burenhult, G. \& Westergaard, S. (eds), Stones and Bones. Formal Disposal of the Dead in Atlantic Europe During the Mesolithic-Neolithic Interface 6000-3000 bc, 115-44. Oxford: British Archaeological Report S1201

Rowley-Conwy, P. 2004. How the West was lost: a reconsideration of agricultural origins in Britain, Ireland and southern Scandinavia. Current Anthropology 45(S4), 83-113

Rowley-Conwy, P. 2011. Westward Ho! The spread of agriculture from Central Europe to the Atlantic. Current Anthropology 52(S4), S431-451

Rowley-Conwy, P. \& Legge, A. 2015. Subsistence practices in Western and Northern Europe. In Fowler, C., Harding, J. \& Hofmann, D. (eds), The Oxford Handbook of Neolithic Europe, 429-46. Oxford: Oxford University Press

Saville, A. 2008. The flint and chert artefacts. In Mercer \& Healy (eds) 2008, 648-743

Saville, A. (ed.), 1990. Hazleton North, Gloucestershire, 1979-82: The excavation of a Neolithic long cairn of the Cotswold-Severn group. London: Historic Buildings and Monuments Commission

Schulting, R.J. 2013. On the northwestern fringes: Earlier Neolithic subsistence in Britain and Ireland as seen 
through faunal remains and stable isotopes. In Colledge, S., Conolly, J., Dobney, K., Manning, K. \& Shennan, S. (eds), The Origins and Spread of Stock-Keeping in the Near East and Europe, 313-38. Walnut Creek: Left Coast Press

Schulting, R.J. 2015. Stable isotopes and Neolithic subsistence: pattern and variation. In Fowler, C., Harding, J. \& Hofmann, D. (eds), The Oxford Handbook of Neolithic Europe, 361-84. Oxford: Oxford University Press

Schwarcz, H.P. \& Schoeninger, M.J. 2011. Stable isotopes of carbon and nitrogen as tracers for paleo-diet reconstruction. In Baskaran, M. (ed.), Handbook of Environmental Isotope Geochemistry, 725-42. Berlin: Springer

Sharp, Z. 2007. Principles of Stable Isotope Geochemistry. Upper Saddle River NJ: Pearson Prentice Hall

Sharples, N. 1991. Maiden Castle: Excavations and field survey 1985-6. London: English Heritage

Slovak, N.M. \& Paytan, A. 2011. Application of Sr isotopes in archaeology. In Baskaran, M. (ed.), Handbook of Environmental Isotope Geochemistry, 743-68. Berlin: Springer

Smith, I.F. 1965. Windmill Hill and Avebury: Excavations by Alexander Keiller, 1925-1939. Oxford: Clarendon Press

Smith, I. F. 1971. Causewayed enclosures. In Simpson, D.D.A. (ed.), Economy and Settlement in Neolithic and Early Bronze Age Britain and Europe: Papers delivered at a conference held in the University of Leicester, December 1969, 89-112. Leicester: Leicester University Press

Smith, I. F. 2008aThe pottery from the hilltop excavations of 1974-82. In Mercer \& Healy (eds). 2008, 587-612

Smith, I. F. 2008bStone axes and adzes, In Mercer \& Healy (eds) 2008, 630-2

Smith, I. F., Roe, F. \& Healy, F. 2008. Chronology and distribution of stone artefacts. In Mercer \& Healy (eds). 2008, 640-7

Sponheimer, M. \& Cerling, T.E. 2014. Investigating ancient diets using stable isotopes in bioapatites. In Holland, H.D. \& Turekian, K.K. (eds), Treatise on Geochemistry, (2 edn) 341-55. Oxford: Elsevier

Thomas, J. 1999. Understanding the Neolithic. London: Routledge
Thomas, J 2013. The Birth of Neolithic Britain: An interpretative account. Oxford: Oxford University Press

Thomas, J. 2016. Cattle, consumption and causewayed enclosures (response to Parmenter, Johnson and Outram). World Archaeology 48(5), 728-44

Warham, J.O. 2011. Mapping biosphere strontium isotope ratios across major lithological boundaries. A systematic investigation of the major influences on geographic variation in the ${ }^{87} \mathrm{Sr} /{ }^{86} \mathrm{Sr}$ composition of bioavailable strontium above the Cretaceous and Jurassic rocks of England. Unpublished PhD Thesis, University of Bradford

Wheeler, M. 1943. Maiden Castle, Dorset. London: Report of the Research Committee of the Society of Antiquaries 12

Whittle, A. 1997. Moving on and moving around: Neolithic settlement mobility. In Topping, P. (ed.), Neolithic Landscapes, 15-22. Oxford: Oxbow Monograph 86

Whittle, A. 2003. The Archaeology of People: Dimensions of Neolithic life. London: Routledge

Whittle, A., Bayliss, A. \& Healy, F (eds). 2011. Gathering Time: Dating the Early Neolithic enclosures of Southern Britain and Ireland. Oxford: Oxbow Books

Whittle, A., Pollard, J. \& Grigson, C. 1999. Interpretations. In Whittle, A., Pollard, J. \& Grigson, C. (eds), The Harmony of Symbols: The Windmill Hill causewayed enclosure, Wiltshire, 347-80. Oxford: Oxbow Books

Willmes, M., McMorrow, L., Kinsley, L., Armstrong, R., Aubert, M., Eggins, S., Falguères, C., Maureille, B., Moffat, I. \& Grün, R. 2013. The IRHUM (Isotopic Reconstruction of Human Migration) database-bioavailable strontium isotope ratios for geochemical fingerprinting in France. Earth System Science Data Discussions 6, 761-77

Wright, L.E. \& Schwarcz, H.P. 1998. Stable carbon and oxygen isotopes in human tooth enamel: identifying breastfeeding and weaning in prehistory. American Journal of Physical Anthropology 106(1), 1-18

Zazzo, A. 2014. Bone and enamel carbonate diagenesis: A radiocarbon prospective. Palaeogeography, Palaeoclimatology, Palaeoecology 416, 168-78

Zienkiewicz, L. 1999. Pottery: Early Neolithic including Ebbsfleet. In Whittle, A., Pollard, J. \& Grigson, C. (eds), The Harmony of Symbols: The Windmill Hill causewayed enclosure, Wiltshire, 258-92. Oxford: Oxbow Books

\section{RÉSUMÉ}

Témoignages isotopiques de l'utilisation du paysage et du rôle des enclos à chaussée empiérrée durant le néolithique ancien dans le sud de la Grande-Bretagne, de Samantha Neil, Jane Evans, Janet Montgomery et Chris Scarre

On a souvent débattu de la nature de l'utilisation du paysage et des configurations des résidences au cours du néolothique britannique ancien. Ici, nous utilisons l'analyse des isotopes d'oxygène et de strontium de l'émail des dents d'individus enterrés dans le complexe monumental à chaussée empiérrée de Hambledon dans le Dorset, Angleterre, pour évaluer les types d'utilisation du paysage au cours du néolithique ancien. Une analyse antérieure donne à penser qu'une proportion conséquente des artifacts trouvés sur le site pourrait avoir son origine dans la lithologie de l'Eocène et du jurassique supérieur et moyen que les enclos dominent 
immédiatement à leur ouest et sud. Les chargés de fouilles ont donc argumenté que le secteur du paysage visible depuis Hambledon Hill fournit un index approximatif pour le captage occupé par les commuanautés qu'il servait. La plus grande partie de la pouplation enterrée rprésente des taux d'isotope qui pourraient être compatibles avec cet argument. Des liens entre Hambledon Hill et des régions bien plus éloignées sont aussi envisagés sur la base de la présence d'artifacts à l'intérieur de faciès qui auraient pu provenir de lithologie du Somerset, du Devon ou des Cornouailles dans le sud-ouest de l'Angleterre. Cependant peu des individus de l'échantillon présentent des taux d'isotope de strontium compatibles avec le fait que pendant leur enfance la majorité de l'alimentation qu'ils auraient reçue serait originaire de ces contrées.Les individus qui montraient les taux d'isotope de strontium les plus élevés étaient tous des hommes adultes qui, proposent les chercheurs, étaient morts au cours d'un ou plusieurs épisodes de conflit, à la suite de l'incendie et de la destruction des ouvrages de défense, construits au cours du 6ème siècle av. J.C., qui les entouraient Au moins un de ces individus, qui fut trouvé avec une pointe de flèche entre les côtes, n'avait pas obtenu son alimentation infantile à proximité et $\mathrm{a}^{87} \mathrm{Sr} /{ }^{86} \mathrm{Sr}$, valeurs qui pourraient être comparables à celles biodisponibles dans la péninsule du sud ouest.

\section{ZUSSAMENFASSUNG}

Isotopen liefern Hinweise auf Landschaftsnutzung und die Rolle von Causewayed Enclosures während des frühen Neolithikums im südlichen Großbritannien, von Samantha Neil, Jane Evans, Janet Montgomery, und Chris Scarre

Die Art der Landschaftsnutzung und der Siedlungsweise während des britischen frühen Neolithikums wurde oft diskutiert. Wir wenden nun Analysen von Strontium- und Sauerstoffisotopen aus dem Zahnschmelz von Individuen an, die im Monumentenkomplex der Causewayed Enclosures (Erdwerke) von Hambledon Hill in Dorset, England, bestattet wurden, um Muster der Landschaftsnutzung während des frühen Neolithikums zu bewerten. Frühere Untersuchungen legen nahe, dass ein bedeutender Teil der Artefakte, die an diesem Fundort geborgen wurden, aus Gesteinsformationen des Eozäns und der Jüngeren bis Mittleren Jurazeit stammen könnten, welche die Monumente nach Westen und Süden überblicken. Die Ausgräber sprachen sich deshalb dafür aus, dass der Abschnitt der Landschaft, der von Hambledon Hill aus sichtbar ist, eine ungefähre Größenangabe der Einzugsregion ist, die von den Gemeinschaften in Anspruch genommen wurden, die den Ort nutzten. Verbindungen zwischen Hambledon Hill und deutlich weiter entfernten Regionen werden ebenfalls hypothetisiert auf der Basis des Vorhandenseins von Artefakten im Fundensemble, die aus Gesteinsformationen aus Somerset, Devon und Cornwall in Südwestengland stammen könnten. Jedoch weisen nur wenige der untersuchten Individuen Anteile an Strontiumisotopen auf, die mit einer überwiegenden Nahrungsaufnahme aus diesen Gebieten in ihrer Kindheit übereinstimmen würden. Jene Individuen, die den höchsten Anteil an Strontiumisotopen aufweisen, sind alle erwachsene Männer, bei denen die Ausgräber annehmen, dass sie während einer oder mehrerer gewalttätiger Episoden starben, die auf das Niederbrennen und Zerstören umliegender Verteidigungsanlagen folgten, die im 36. Jahrhundert BC erbaut worden waren. Zumindest eines dieser Individuen, das mit einer Pfeilspitzen zwischen seinen Rippen gefunden wurde, hat seine Nahrung während der Kindheit nicht lokal bezogen und zeigt ${ }^{87} \mathrm{Sr} /{ }^{86} \mathrm{Sr}$-Werte auf, die mit jenen vergleichbar sein könnten, die natürlich auf der Südwesthalbinsel verfügbar sind.

\section{RESUMEN}

Evidencia isotópica del uso del paisaje y el papel de los recintos con acceso durante el Neolítico inicial en el sur de Gran Bretaña, por Samantha Neil, Jane Evans, Janet Montgomery, y Chris Scarre

La naturaleza del uso del paisaje y de los patrones de hábitat durante el Neolítico inicial en Gran Bretaña ha sido continuamente debatida. En este artículo empleamos el análisis de isótopos de estroncio y oxígeno del esmalte dentario de los individuos enterrados en Hambledon Hill, un recinto monumental en Dorset, Inglaterra, para 
evaluar los patrones del uso del paisaje durante el Neolítico inicial. Los análisis previos sugieren que una proporción significativa de los artefactos documentados en el yacimiento podrían haberse elaborado a partir de litologías del Eoceno y el Jurásico Medio y Superior accesibles en los entornos inmediatos al sur y al este de los recintos. Por tanto, los arqueólogos argumentaron que el sector de paisaje visible desde Hambledon Hill daba una idea aproximada del espacio geográfico explotado por las comunidades que albergaba el recinto. La mayoría de la población enterrada presenta ratios isotópicos que podrían ser consistentes con esta hipótesis. También se han propuesto conexiones entre Hambledon Hill y regiones más alejadas, basándose en la presencia, entre los conjuntos de materiales, de artefactos que podrían haber sido realizados a partir de las litologías identificadas en Somerset, Devon y Cornwall en el suroeste de Inglaterra. Sin embargo, son pocos los individuos muestrados que presentan valores isotópicos de estroncio compatibles con una dieta procedente de estas áreas durante la infancia. Los individuos que exhiben las mayores proporciones de isótopos son adultos masculinos, cuyas muertes se supone que fueron resultado de uno o más episodios de conflicto, después de la quema y destrucción de las estructuras defensivas circundantes en el siglo 36 BC. Al menos uno de estos individuos, que fue encontrado con una punta de fecha entre sus costillas, no refleja una dieta infantil local y presenta valores de ${ }^{87} \mathrm{Sr} /{ }^{86} \mathrm{Sr}$ que podrían ser comparables con los disponibles en el sudoeste de la península. 